\title{
The influences of cycle stage and pregnancy upon cell glycosylation in the endometrium of the mare
}

DOI:

10.1016/j.theriogenology.2020.05.007

\section{Document Version}

Accepted author manuscript

Link to publication record in Manchester Research Explorer

\section{Citation for published version (APA):}

Jones, C. J. P., Aplin, J. D., Allen, W. R., \& Wilsher, S. (2020). The influences of cycle stage and pregnancy upon cell glycosylation in the endometrium of the mare. Theriogenology, 154, 92-99.

https://doi.org/10.1016/j.theriogenology.2020.05.007

\section{Published in:}

Theriogenology

\section{Citing this paper}

Please note that where the full-text provided on Manchester Research Explorer is the Author Accepted Manuscript or Proof version this may differ from the final Published version. If citing, it is advised that you check and use the publisher's definitive version.

\section{General rights}

Copyright and moral rights for the publications made accessible in the Research Explorer are retained by the authors and/or other copyright owners and it is a condition of accessing publications that users recognise and abide by the legal requirements associated with these rights.

\section{Takedown policy}

If you believe that this document breaches copyright please refer to the University of Manchester's Takedown Procedures [http://man.ac.uk/04Y6Bo] or contact uml.scholarlycommunications@manchester.ac.uk providing relevant details, so we can investigate your claim.

\section{OPEN ACCESS}


Revised 2.

The influences of cycle stage and pregnancy upon cell glycosylation in the endometrium of the mare

$$
\begin{aligned}
& \text { Carolyn J.P. Jones }{ }^{\mathrm{a}^{*}} \\
& \text { John D. Aplin } \\
& \text { W. R. (Twink) Allen }
\end{aligned}
$$

Sandra Wilsher ${ }^{\mathrm{b}}$

${ }^{a}$ Maternal and Fetal Health Research Centre, Division of Developmental Biology \& Medicine, School of Medical Sciences, Faculty of Biology, Medicine and Health, University of Manchester, Central Manchester University Hospital NHS Foundation Trust, Manchester Academic Health Sciences Centre, St Mary's Hospital, Oxford Road, Manchester M13 9WL ${ }^{b}$ Sharjah Equine Hospital, Bridge No 6, Al Daid Road, Al Atain Area, Sharjah, United Arab Emirates.

*Corresponding author: Carolyn Jones, PhD, DMedSc, Maternal and Fetal Health Research Centre, $5^{\text {th }}$ Floor (Research), St Mary's Hospital, Hathersage Road, Manchester M13 OJH, UK.

Email addresses: carolyn.jones@manchester.ac.uk (C.J.P. Jones), twinkallen100@gmail.com (W.R. Allen), john.aplin@manchester.ac.uk (J.D. Aplin), sandrawilsher@hotmail.co.uk (S. Wilsher) 


\section{Abstract}

2 From Day 6.5-7 post-conception until its loss around Day 22, the equine embryo is enclosed

3 in a mucinous capsule that prevents direct intercellular interaction between the

4 trophectoderm and uterine epithelium. The embryo is, however, bathed in glycoprotein-rich

5 secretions. In this study, lectin histochemistry was used to characterise the distribution and

6 glycan composition of uterine glycoproteins destined for secretion, and to ascertain the

7 local effect of an embryo on glycosylation in the endometrium. Endometrial biopsies were

8 taken from mares in estrus, on Days 5, 8, 12 and 15 of diestrus, and on Days 12 and 15 of

9 pregnancy and processed for lectin histochemistry. During estrus, lumenal epithelial cells were as truncated pyramids and mainly non-ciliated with glycosylated granules in the cytoplasm. Occasional ciliated cells contained few granules. Five days post-ovulation, nonciliated cells of the lumenal epithelium were taller, and had accumulated many highly glycosylated apical granules. By Days 12 and 15 post-ovulation these cells were more cuboidal and some showed fewer secretory granules. In marked contrast, by Days 12 and 15 of pregnancy, the ciliated cells were distended, with numerous granules but non-ciliated cells had only a few in the apical cytoplasm. Glycosylation changed dramatically in pregnancy in the luminal and superficial gland epithelium, with fewer fucosylated termini, more $\mathrm{N}$-acetyl galactosamine residues, together with an overall reduction in sialic acid and several other sugar structures. Glycosylation in ciliated cells on Days 12 and 15 of pregnancy showed a striking similarity to that of the blastocyst capsule. The data strongly suggests that glycoprotein production by luminal epithelial cells is influenced by the presence of a conceptus. We speculate that, as well as providing nourishment for the developing embryo, epithelial secretory glycoproteins may contribute components to the capsule, which develops only partially in embryos cultured in vitro. 


\section{Introduction}

The mammalian uterus, where cyclic changes regulate interaction with spermatozoa, the embryo and the placenta, is particularly rich in glycan expression $[1,2]$. Endometrial glands, in particular, produce secretions rich in glycoproteins and mucins that play a role in the provision of a suitable environment for the preimplantation embryo [3]. Striking variations in the uterine glycan repertoire are seen, both through the various stages of reproductive cycles and between different species [4-6]. A spatially-resolved glycosylation profile of a target tissue of interest can be derived by exposing serial sections to a panel of reportertagged carbohydrate-binding proteins known as lectins [7].

The horse conceptus is unique in that it does not make stable contact with the uterine epithelium until 40 to 42 days after ovulation [8]. The embryo enters the uterus on Day 6 after ovulation and from then until Day 16-17 it moves constantly around the uterine lumen, driven by peristaltic contractions of the myometrium stimulated by pulsatile releases of PGF2 $\alpha$ (muscle contractant) and $\mathrm{PGE}_{2}$ (relaxant) from the trophoblast [9]. During this period the conceptus remains spherical and is surrounded by the equine-unique blastocyst capsule, which is secreted initially by the early trophoblast shortly after the embryo enters the uterus $[10,11]$. This mucin-like glycoprotein capsule persists until around Day 22 when it begins to disintegrate. The capsule fails to develop correctly in embryos cultured in vitro [12], suggesting that uterine secretions may support its production and/or maintenance. Conversely, we do not know if the mobility of the equine embryo has any effect upon the secretions produced by the endometrium, although movement of the vesicle within and between the uterine horns has been proposed to have a role in physiological or metabolic exchanges between the vesicle, uterine luminal fluids or the endometrium [13].

We hypothesised that lectin histochemistry would enable us to test the hypothesis that endometrial epithelial differentiation and secretory activity are affected by the presence of a conceptus, and provide evidence that uterine secretions might contribute to capsule formation. 


\section{Materials and Methods}

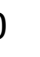

The equine endometrium was studied from estrus to Day 15 of diestrus and days 12 to 15 of pregnancy to allow comparison between non-pregnant states and pregnancy. The endometrium comprises the luminal epithelium and the lamina propria that extends from its basal lamina to the myometrium. The lamina propria is packed with endometrial glands each opening into the uterine lumen, and surrounded by stromal cells in the upper part of the lamina - the stratum compactum - and by a loose arrangement of interconnecting cells in the lower stratum spongiosum. The morphology and degree of coiling of the glands alter with the stage of the oestrous cycle and these changes in gland histology and their quantity of intraluminal secretions are well documented [14, 15].

Endometrial biopsies were obtained from cycling and early pregnant nulliparous Arabian mares 3 to 8 years old maintained at Sharjah Equine Hospital (Sharjah, U.A.E), with approval from the Hospital Ethical Committee. The mares were all of known fertility with no uterine pathology. Ovulation (Day 0) and pregnancy were confirmed by transrectal ultrasonography. Biopsies were taken from a total of 16 mares with some biopsied on two occasions at different stages of consecutive estrous cycles. All mares had shown at least one normal cycle prior to the study and those sampled during estrus went on to ovulate normally, confirmed by transrectal ultrasonography and a rise in peripheral progesterone concentrations. As estrus is such a variable length in the mare, biopsies taken during estrus $(n=3)$, were collected when mares exhibited an oedema pattern of $\geq 3$ (scale 1 to 4 , with 4 being the greatest) and exhibited a follicle on their ovaries $\geq 30 \mathrm{~mm}$. Further biopsies were taken on Days 5, 8, 12 and 15 of diestrus ( $n=3$ at each time point) and Days 12 and 15 of pregnancy ( $n=3$ at each time point). In non-pregnant mares biopsies were taken from the base of the left or right horn. In pregnant mares transrectal ultrasound examination using a Sonosite $\mathrm{M}-$ Turbo- $\mathrm{C}$ with a $7.5 \mathrm{MHz}$ linear probe prior to the biopsy determined the site of the embryo in the uterus and Yeoman's biopsy forceps were directed to the base of that uterine horn. The biopsies were fixed in $10 \%$ neutral buffered formalin. Thin slices (approximately $1 \mathrm{~mm}$ ) were post-fixed in $2.5 \%$ glutaraldehyde in $0.1 \mathrm{M}$ sodium cacodylate buffer pH 7.3 for 2 hours before being embedded in epoxy resin (Taab Laboratory Equipment, Aldermaston, UK) for lectin histochemistry. This was performed as described previously [16] using a panel of 24 lectins (see Table 1 for lectins used and their 
specificities). Some sections were pre-treated with Type VI neuraminidase from Clostridium perfringens (Sigma, 0.1 units $/ \mathrm{ml}$ in $0.2 \mathrm{M}$ acetate buffer $\mathrm{pH}$ 5.5. with $1 \%$ calcium chloride) for $2 \mathrm{~h}$ at $37^{\circ} \mathrm{C}[17]$ to cleave off terminal sialic acid residues before staining with AHA, ECA, SBA, SNA-1, MAA, PAA and WGA. Controls were performed as described previously [16]. Lectin binding was assessed using a semi-quantitative ranking system of analysis, where staining density was allocated a grade from 0 (unstained) to 4 (intensely stained) and granule distribution from -/+ (very sparse) to +++ (abundant) [16]. Images were captured on an Olympus microscope with Image-ProPlus software (Media Cybernetics, Rockville, MD, USA) using $\times 10$ and $\times 40$ objectives.

\section{Results}

\subsection{Lumenal epithelium (Average values are summarised in Tables 2 and 3). Typical changes} in glycosylation are well illustrated by the lectin VVA (Figure 1).

\subsubsection{Estrus}

During estrus, the cells of the lumenal epithelium were irregular and resembled truncated pyramids or frustra in shape, and measuring $10-20 \mu \mathrm{m}$ in height (Fig. 1A), with the majority having a microvillous surface. Occasional ciliated cells were visible, often near gland openings on the lumenal surface. Both the microvillous and ciliated apical surfaces were very heavily glycosylated, binding all lectins apart from $B S A-1 B_{4}$, although weakly with MAA. A variable number of apical granules could be seen, some individual but others in clumps, the latter mainly in the non-ciliated cells. These inclusions were stained by most lectins (Figs 1A, 3F), but only weakly by I-PHA, LTA and MAA. A subpopulation bound CONA,

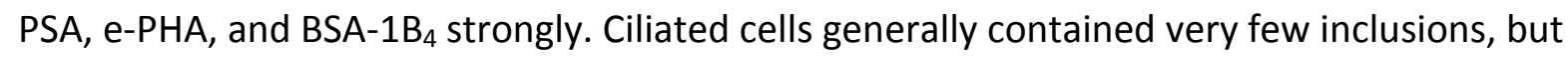
those that were present tended to have similar binding characteristics to those in the nonciliated cells.

\subsubsection{Diestrus, Days 5-15}

By Day 5 post-ovulation, the epithelial cells were more regular and columnar in shape and were now 20-25 $\mu \mathrm{m}$ high, many more ciliated cells being present (Fig. 1B); the distinction between cells with or without cilia was now more marked. The supranuclear 
areas of non-ciliated cells were packed full of secretory granules which were heavily

124 glycosylated, as evidenced by strong binding of lectins including LTA and SBA (Figs 2A, D);

125 PSA, DBA, VVA (Fig. 1B), BSA-1B 4 , WFA, and STA showed more moderate binding, and I-PHA

126 and MAA bound only weakly (Fig. 3A). The microvillous surface also bound the lectins

127 strongly, apart from I-PHA and MAA. The majority of ciliated cells had only a few, sparse

128 supranuclear inclusions which stained with all the lectins except for $\mathrm{BSA}-1 \mathrm{~B}_{4}$, as did the

129 apical surface. Little change was evident at Day 8 post-ovulation (Fig. 1D), but by Day 12

and especially Day 15 (Figs 1E, F, 2B), in the absence of an embryo, non-ciliated cells showed greater heterogeneity in lectin binding and incidence of secretory granules, suggesting that there had been some release of intracellular glycan; by day 15 they were shorter, about 10 $15 \mu \mathrm{m}$ in height. Cilia were very prominent by this stage, with some intracellular supranuclear secretory material (Figs 1E, F, 2E) present in the ciliated cells.

\subsubsection{Pregnancy, Days 12 and 15}

The presence of an embryo in the uterus induced a dramatic change in the morphology of the lumenal epithelium and its glycosylation. At Day 12 of pregnancy, the ciliated cells, though similar in height to their non-pregnant counterparts, had become goblet-shaped and swollen with apically concentrated secretory granules, but with fewer and more ragged cilia (Fig. 1G); by Day 15 they appeared rounder and their cilia looked even more degenerate (Fig. $1 \mathrm{H}$ ). As in the non-pregnant state, the abundant granules bound most of the lectins (see Table 2 and Figs $1 \mathrm{H}, 2 \mathrm{~F}, \mathrm{G}, \mathrm{H}, \mathrm{K}$,) but they were virtually unstained with lectins I-PHA, LTA, UEA-1 and MAA (Figs 2C, I). Occasional dark inclusions were seen in the case of AHA, SNA-1 and PAA (Fig. 2K). In many cases, the staining was concentrated in the upper areas of the cell as can be seen with SBA and PAA (Figs 2F, K).The occasional inclusions that bound MAA appeared to be located in the area of the Golgi apparatus, just above the nucleus.

The non-ciliated cells which, during the cycle, were full of secretions, now contained only sparse inclusions in an otherwise clear cytoplasm. The apical surface still bound most lectins apart from MAA and the occasional inclusions that were present had now lost all their binding to LTA (Fig. 2C) , UEA-1 and MAA, but otherwise, the same lectins stained as seen on Day 15 post-ovulation in non-pregnant mares. 
Pretreatment with neuraminidase had very little effect on the staining of the lumenal epithelial cells with respect to AHA, ECA, SBA, PAA (Fig. 2L) and WGA but, as expected, there was diminution of binding of the sialic acid-specific lectins SNA-1 and MAA (Fig. 3A).

\subsection{Glandular epithelium}

The results of the lectin staining in the glands are summarised in Table 3. Cell shading has been used to show changes in staining intensity in the upper, mid and basal portions of the endometrial glands at four different time points. The stated values are only approximate and they aim to illustrate the trend since great variation was evident between different gland profiles.

For many of the lectins significant differences in glycosylation existed between the upper and basal portions of glands, with staining intensity diminishing from the surface to the basal regions (see Table 3), apart from MAA (Fig. 3A) which was strongest basally. Other lectins bound more or less uniformly down the gland (CON A, PSA, e-PHA, UEA-1, ALA, DSA, STA and SNA-1) while pretreatment with neuraminidase increased staining with AHA and ECA and to a lesser extent SBA, making staining also more uniform (Fig. 3 F, G). There was virtually no binding with I-PHA and LTA showed only weak binding. Unlike the lumenal epithelium, staining of the glands did not alter greatly with the onset of pregnancy (see Table 3), with the exception that the upper part of the gland generally took on the characteristics of the lumenal epithelium, as can be seen in Fig $1 G$.

The uppermost parts of the glands were composed of cells very like those constituting the lumenal epithelium and they showed the same staining properties. Tufts of highly glycosylated cilia were visible and other apical surfaces of the cells bore microvilli which bound most lectins apart from I-PHA. Coarse granular supranuclear upper gland staining was seen with AHA (Fig. 3B) and MPA during estrus and up until Day 8 postovulation.

The mid-regions of the glands were composed of narrow, columnar cells with microvilli and basally situated nuclei; masses of glycan-rich granules were evident between the nuclei and apical surface. With some lectins, these granules appeared to be hollow (Fig. 3C). Generally, the staining was fairly uniform in nature despite the glands containing both secretory and ciliated cell types. However, with WFA there was very heterogeneous binding 
to the cells of the mid-portion and, later, also the basal portion of the glands, with some darkly stained cells adjacent to completely unstained ones (Fig 3D). This was also seen with DBA and, to a lesser extent, with VVA (Fig. 1C). The fact that lateral and basal areas of the cells were stained made this even more striking.

Sometimes there was darker staining just above the nucleus which may have reflected the position of the Golgi apparatus; this was particularly evident with ALA, AHA, ECA, SBA, SNA-1 (Fig. 3E) and WGA and MAA and, in general but apart from MAA, was enhanced after neuraminidase pretreatment. In the basal regions of the glands there was weak or no binding with LTA, DBA, VVA, BSA-1B, $\mathrm{HPA}, \mathrm{AHA}$ and SBA, with some variability between gland profiles. DBA binding varied, being low during estrus and variable after ovulation.

Secretory material was sometimes detected in gland lumenae, especially towards the basal portions. Occasionally, widely dilated lumenae were seen, which contained heterogeneous secretory material. The secretions bound most of the lectins tested except for I-PHA, BSA-1B ${ }_{4}$ and $\mathrm{AHA}$ (without neuraminidase), consistent with the progressive release of glycoprotein from intracellular stores. In the cases of three lectins (SBA, ECA and AHA) that recognise structures in which subterminal galactose in either $\mathrm{O}$ - or $\mathrm{N}$-linked glycans can be capped by sialic acid, thus inhibiting binding of the lectin, neuraminidase pretreatment increased the staining of secretions (Fig $3 \mathrm{H}, \mathrm{I}$ ), most notably in the mid- tobasal parts of the glands. Staining with MAA, which binds sialic acid, was reduced by neuraminidase pretreatment (Fig, 3A), providing a control for the assay.

\section{Discussion}

There have been few studies to date on uterine glycosylation in the mare. Some early work used lectins labelled with FITC to show endometrial fucose and N-acetyl glucosamine, both of which increased after implantation [18], while a limited panel of lectins was used to assess changes that occurred in chronic endometrial degeneration [19]. Jones et al. [20] examined pre-and post-implantation stages of equine pregnancy with a panel of 15 lectins and demonstrated changes occurring between Days 37 and 50 associated with commencing attachment and the start of interdigitation of the trophoblast with the endometrium. Here, we have observed changes during the oestrous cycle and early pregnancy that we postulate may be relevant to the early embryo-endometrial dialogue. 
A progressive build-up of richly and diversely glycosylated granules in non-ciliated lumenal epithelial cells is seen between Days 0 and 5 . Important features include an intense concentration of L-fucosyl residues (LTA), moderate levels of $\mathrm{N}$-acetyl galactosaminecontaining structures (DBA, VVA, WFA) and weak $\alpha 2,3$-linked sialylation (MAA). It is probable that the intracellular granules are destined for secretion as the uterus prepares itself for the possible arrival of an embryo on Day 6 post ovulation [21]. In the absence of an embryo, they gradually diminish over the next few days.

The presence of an embryo dramatically changes the lumenal epithelium with respect to both the morphology and biochemistry of the cells compared to the equivalent period during diestrus. The non-ciliated cells now contain virtually no inclusions, while ciliated cells are distended into goblet shapes with granules that contain many classes of glycan, often clustering in the apical parts of the cell where the Golgi apparatus is located [22]. Especially abundant are DBA-binding blood group A residues (GalNAca1,3(LFuc $\alpha 1,2)$ Galß1,3/4GIcNAc ß1) and shorter N-acetylgalactosamine sequences (VVA), also N-acetyl glucosamine oligomers (STA, LEA and WGA); almost all of these are absent or sparse in ciliated cells in the non-pregnant state (see Table 2). Most striking, however, is the loss in pregnancy of specific non-reducing terminal residues including $\alpha 1,2-$ linked fucose (LTA, UEA-1) from both lumenal cell types. This suggests either an embryonic fucosidase activity or a juxtacrine action to reduce epithelial fucosylation. We [2] and others [23-25] have previously pointed to fucosylated oligosaccharides as influencing embryo-epithelial interactions at implantation in mouse [23], human [24-25] and a wide range of animal species [2] with mainly epitheliochorial and haemochorial placentation. Another terminal sugar, a2,3-linked sialic acid, also declines, as revealed by diminished binding of MAA.

A striking finding of this study is the shift during early pregnancy of glycoprotein production to ciliated goblet cells. Glycosylation has been reported previously in both ciliated and non-ciliated cells of the oviducal isthmus [26] and ampulla of the horse [27] during the oestrous cycle and pregnancy. Ciliated cells with secretory characteristics have been observed in single cell RNAseq profiles of human endometrial epithelial cells [28]. As shown in the rabbit oviduct, secretory granules can be exocytosed between the basal bodies or kinetosomes of cilia [29].

An acellular capsule surrounds the blastocyst from Day 6.5-7 post-ovulation until its loss around Day 22 [10]. Between Days 6 and 16 after ovulation, the conceptus moves 
constantly throughout the uterine lumen, accruing mass up to Day $18[10,30]$ and expanding from a diameter of $150-220 \mu \mathrm{m}$ on Day 6 to around $2.5-2.8 \mathrm{~cm}$ on Day 21 [31]. It also doubles in weight during this time, suggested to be due to its accumulation of proteins and other components from uterine secretions [32]. The capsule is composed of mucins high in galactosyl and $\mathrm{N}$-acetylgalactosamine residues after Day 10 of pregnancy, with less $\mathrm{N}$-acetylglucosamine and little $\mathrm{N}$-glycan, suggesting it is heavily $\mathrm{O}$-glycosylated [33]. Although fucose was analysed in that study [33], there was no specific mention of it in the results, implying it was not a major constituent [33]. Low levels of free sialic acid were detected but cryptic sites were revealed after neuraminidase pretreatment. Thus, the glycan profile observed in goblet cells during pregnancy, with little fucose and increases in galactose and $\mathrm{N}$-acetylgalactosamine appears to be similar to that of the capsule. It is tempting, therefore, to postulate that the lumenal epithelial and gland secretions may contribute to its formation. Indeed, although it has been shown that the major part of the capsule is produced initially by the trophoblast $[10,11]$, its inability to form correctly in vitro [12] suggests that the uterine environment is essential for its development. Furthermore, demi-embryos that had lost their capsule during bisection to produce monozygotic twins developed a new capsule when transferred to the uteri of recipient mares [34].

It has also been suggested that 0 -linked glycoproteins in mucins have a fundamental role in cell-cell interactions [35], and that the capsule itself may be involved in signalling between the embryo and the endometrium. Movement of the embryo within the uterine lumen might even act as a stimulus to the lumenal epithelial cells. It has recently been shown in an ungulate (roe deer) that luminal uterine epithelium can sense the presence of the elongated embryo [36] and factors secreted from the equine conceptus may elicit a similar response. The capsule's anti-adhesive property and its net negative charge conveyed by sialic acid may well assist the equine embryo to move around within the uterus [30]; the sialidase NEU2 has been identified in the equine conceptus transcriptome [37], with mRNA levels increasing between Days 6 and 14, and this may be linked to the observed loss of sialic acid at later stages [38]. Sialic acid in $\alpha 2,3$-linkage (MAA) on the lumenal epithelium was found to be reduced in early pregnancy which could also promote attachment by reducing the surface negative charge. prior to the establishment of haemotrophic nutrition by the allantochorionic placenta. It 
has already been shown that the endometrial glycoprotein uterocalin, a lipocalin which has one $N$-glycosylation site $[41,42]$ binds to the capsule surrounding the equine embryo $[43$, 44], acting as a carrier or transport protein for such nutrients as essential lipids and amino acids [45-47]. Uterocalin has been detected immunohistochemically in the maternal epithelium during diestrus and throughout pregnancy, with higher expression in early stages [48]. Other glycosylated secretory products such as uteroferrin and uteroglobin, which both carry $\mathrm{N}$-glycosylation sites [48-50] have been identified in the lumenal epithelium and glands of the pregnant mare, as well as MUC-1 [51] which is maintained throughout pregnancy in the equid, unlike the situation in rodents, primates, ruminants and pigs [52] in which it is reduced on contact with trophoblast. Leukaemia inhibitory factor (LIF), produced by gland epithelial cells, is also present in uterine fluid [53], and is heavily glycosylated [54] with both $N$ and $O$-linked sites. With respect to histotroph production, the binding of MAA to $\alpha 2,3$-linked sialic acid was lost in the upper parts of the endometrial glands implying that residues initially sialylated lost their sialic acid prior to secretion, possibly to render the histotroph molecules more easily broken down by the conceptus [55] as well as to make the surface less negatively charged. With most glycans, however, there is an increase in staining intensity from the basal regions towards the apical, implying subtle modulation of the glycosylation machinery along the duct. It was also noted that, despite their being two cell types reported in the literature [22] - secretory and ciliated cells - the binding of the lectins was usually generally uniform apart from that of WFA, DBA and VVA as can clearly be seen in Figure 3, implying that both cell types contribute to glycan biosynthesis.

While it is well established that progesterone can both stimulate secretory behaviour in endometrial cells $[4,56]$ and influence the fixation of the embryo [57] this study has revealed that the cellular source of secretions from the endometrial lumenal epithelium changes dramatically in response to the presence of a conceptus, indicating a novel role for cell diversity in the epithelial response. Juxtacrine signalling could occur via release of oestrogen by the conceptus $[58,59]$; there is evidence that steroids can regulate both $\mathrm{N}$ and $O$-glycosylation, especially terminal sialylation and fucosylation [60]. The numerous polypeptide mediators present in the embryonic secretome may also be influential $[37,61]$.

311 The switch from microvillous to ciliated cells as the main reservoir of glycoprotein suggests a two stage secretory process, with initial release from microvillous cells controlled through 
endocrine pathways and conceptus-derived signals targeting the ciliated cell population in pregnancy.

In conclusion, lectin histochemistry has enabled distinctive changes in cell glycosylation to be observed resulting from the presence of a conceptus in the uterus. It has also provided some evidence that glycoprotein secretions in pregnancy contribute to the unique equine blastocyst capsule as well as providing nourishment for the developing embryo.

Conflicts of interest: The authors declare that they have no competing interests.

Funding: This research did not receive any specific grant from funding agencies in the public, commercial, or not-for-profit sectors.

\section{References}

[1] Carson DD. The glycobiology of implantation. Front Biosci 2002;7:1535-44.

[2] Aplin JD, Jones CJ. Fucose, placental evolution and the glycocode. Glycobiology 2012;22:470-8.

[3] Clark GF. Functional glycosylation in the human and mammalian uterus. Fertil Res Pract. 2015;1: 17.

[4] Jones CJ, Fazleabas AT, McGinlay PB, Aplin JD. Cyclic modulation of epithelial glycosylation in human and baboon (Papio anubis) endometrium demonstrated by the binding of the agglutinin from Dolichos biflorus. Biol Reprod 1998;58:20-7.

[5] Jones CJ, Aplin JD. Glycosylation at the fetomaternal interface: does the glycocode play a critical role in implantation? Glycoconjugate J 2009;26:359-66.

[6] Jones CJP, Aplin JD. Reproductive glycogenetics - a critical factor in pregnancy success and species hybridisation. Placenta 2009;30:216-9.

[7] Manning JC, Romero A, Habermann F, Garcia Caballero G, Kaltner H and Gabius H-J. Lectins: A primer for histochemists and cell biologists. Histochem Cell Biol 2017;147:199222.

[8] Allen WR, Wilsher S. A review of implantation and early pregnancy in the mare. Placenta 2009; 30: 1005-15.

[9] Allen WR, Stewart F. Equine placentation. Reprod Fertil Dev. 2001;13(7-8):623-34. 
[10] Oriol JG, Sharom FJ, Betteridge KJ. Developmentally regulated changes in the

346 glycoproteins of the equine embryonic capsule. J Reprod Fert 1993;99:653-64.

347 [11] Albihn A, Waelchli RO, Samper J, Oriol JG,B. Croy A, Betteridge KJ. Production of capsular material by equine trophoblast transplanted into immunodeficient mice.

349 Reproduction 2003;125:855-63.

350 [12] Tremoleda JL, Stout TA, Lagutina I, Lazzari G, Bevers M M, Colenbrander B et al. Effects of in vitro production on horse embryo morphology, cytoskeletal characteristics, and blastocyst capsule formation. Biol Reprod 2003;69:1895-906.

353 [13] Ginther OJ. Mobility of the early equine conceptus. Theriogenology 1983;19:603-11.

354 [14] Hammond J, Wodzicki K. Anatomical and histological changes during the oestrus cycle in the mare. Proc Roy Soc B 1941; 130:1-12.

356 [15] Kenney RM. Cyclic and pathologic changes of the mare endo-metrium as detected by biopsy, with a note on early embryonicdeath. J Am Vet Med Assoc 1978;172:241-62 [16] Jones CJP, Carter AM, Enders AC. Glycosylation at the fetomaternal interface in haemomonochorial placentae from five widely separated species of mammal: is there evidence for convergent evolution? Cells Tiss Org 2007;185:269-84. glycoconjugates. 2. Beta-galactosyl residues in $\mathrm{O}-$ and $\mathrm{N}$-linked glycans in seminiferous tubules. Histochem J 1992;24:327-36.

[18] Whyte A, Allen WR. Equine endometrium at pre-implantation stages of pregnancy has specific glycosylated regions. Placenta 1985, 6:537-42. [19] Walter I, Klein M, Handler J, Aurich JE, Reifinger M, Aurich C. Lectin binding patterns of uterine glands in mares with chronic endometrial degeneration. Am J Vet Res 2001;62:8405.

369 [20] Jones CJP, Wooding FBP, Dantzer V, Leiser R, Stoddart RW. A lectin binding analysis of 370 glycosylation patterns during development of the equine placenta. Placenta 1999;20:45-57. 371 [21] Battut I, Colchen S, Fieni F, Tainturier D and Bruyas JF Success rates when attempting to nonsurgically collect equine embryos at 144,156 or 168 hours after ovulation. Equine Vet J

373 (Suppl)1998;25:60-2.

374 [22] Tunón A-M,Rodriguez-Martinez H, Haglund A, Albihn A, Magnusson U, Einarsson S. 375 Ultrastructure of the secretory endometrium during oestrus in young maiden and foaled mares. Equine Vet J 1995;27:382-8. 
377 [23] Jasper MJ, Care AS, Sullivan B, Ingman WV, Aplin JD, Robertson SA. Macrophage-

378 derived LIF and IL1B regulate alpha(1,2)fucosyltransferase 2 (Fut2) expression in mouse

379 uterine epithelial cells during early pregnancy. Biol Reprod 2011;84:179-88.

380 [24] Yu M, Wang J, Liu S, Wang X, Yan Q. Novel function of pregnancy-associated plasma

381 protein A: promotes endometrium receptivity by up-regulating $\mathrm{N}$-fucosylation. Sci

382 Rep 2017;7:5315. doi: 10.1038/s41598-017-04735-0.

383 [25] Zheng Q, Zhang D, Yang YU, Cui X, Sun J, Liang C et al. MicroRNA-200c impairs uterine 384 receptivity formation by targeting FUT4 and $\alpha 1,3-$ fucosylation. Cell Death Differ 385 2017;24:2161-72. doi: 10.1038/cdd.2017.136.

386 [26] Desantis S, Acone F, Corriero A, Deflorio M, Zubani D, Ventriglia G, Palmieri G, De Metrio G. Distribution of sialoglycoconjugates in the oviductal isthmus of the horse during anoestrus, oestrus and pregnancy: a lectin histochemistry study. Eur J Histochem 2004;48:403-12.

390 [27] Desantis S, Ventriglia G, Zubani D, Corriero A, Deflorio M, Acone F, Palmieri G, De Metrio G. Differential lectin binding patterns in the oviductal ampulla of the horse during oestrus. Eur J Histochem 2005;49:139-49.

393 [28] Wu B, Li Y, Liu Y, Jin K, Zhao K, An C et al. Cell atlas of human uterus. Biol Rxiv 2018 394 (doi.org/10.1101/267849).

395 [29] Mechant H. Secretory granules in ciliated cells of the rabbit oviduct. Expl Cell Res 396 1969;56: 171-2.

397 [30] Oriol JG. The equine embryonic capsule: practical implications of recent research. 398 Equine Vet J 1994;26:184-6.

399 [31] Betteridge KJ, Eaglesome MD, Mitchell D, Flood PF, Beriault R. Development of horse 400 embryos up to twenty-two days after ovulation: observations on fresh specimens. J Anat $401 \quad 1982 ; 135: 191-209$.

402 [32] Amoroso EC. Placentation. In: Parkes AS, editor. Marshall's Physiology of Reproduction, 403 London: Longmans, Green and Co Ltd; 1952, p. 127-311.

404 [33] Oriol JG, Betteridge KJ, Clarke AJ, Sharom FJ. Mucin-like glycoproteins in the equine 405 embryonic capsule. Mol Reprod Dev 1993;34:255-65.

406 [34] McKinnon AO, Carnevale EM, Squires EL, Carney NJ, Seidel GE. 1989. Bisection of 407 equine embryos. Equine Vet J 1989;8(Suppl.):129-33.

408 [35] Jentoft N. Why are proteins O-glycosylated? Trends Biochem Sci 1990;15:291-4. 

MP et al. Endometrial luminal epithelial cells sense embryo elongation in the roe deer independent of interferon-tau. Biol Rep 2019;101:882-92.

412 [37] Klein C, Troedsson MHT. Transcriptional profiling of equine conceptuses reveals new 413 aspects of embryo-maternal communication in the horse. Biol Reprod 2011;84:872-85.

414 [38] Arar S, Chan KH, Quinn BA, Waelchli RO, Hayes MA, Betteridge KJ, Monteiro MA. 415 Desialylation of core type 1 O-glycan in the equine embryonic capsule coincides with 416 immobilization of the conceptus in the uterus. Carbohydr Res 2007;342:1110-5.

417 [39] Enders AC, Carter AM. Comparative placentation: some interesting modifications for 418 histotrophic nutrition - a review. Placenta 2006; 27 ( Suppl):11-6.

419 [40] Jones CJ, Choudhury RH, Aplin JD. Tracking nutrient transfer at the human maternofetal 420 interface from 4 weeks to term. Placenta 2015;36:372-80.

421 [41] Crossett B, Allen WR, Stewart F. A 19 kDa protein secreted by the endometrium of the 422 mare is a novel member of the lipocalin family. Biochem J 1996;320:137-43.

423 [42] Smits K, Govaere J, Peelman L, Goossens K, de Graaf DC, Vercauteren D et al. Influence 424 of the uterine environment on the development of in vitro-produced equine embryos.

425 Reproduction 2012;143:173-81.

426 [43] Stewart F, Charleston B, Crossett B, Barker PJ, Allen WR. A novel uterine protein that 427 associates with the embryonic capsule in equids. J Reprod Fertil 1995;105:65-70.

428 [44] Stewart F, Kennedy MW, Suire S. A novel uterine lipocalin supporting pregnancy in 429 equids. Cell Mol Life Sci 2000;57:1373-8.

430 [45] Suire S, Stewart F, Beauchamp J, Kennedy MW. Uterocalin, a lipocalin provisioning the 431 preattachment equine conceptus: fatty acid and retinol binding properties, and structural 432 characterization. Biochem J 2001;356:369-76.

433 [46] Kennedy MW. Uterocalin - a provisioning protein for the equine conceptus? In 434 Proceedings of a workshop on the equine placenta. Kentucky Agricultural Experimental 435 Station, University of Kentucky, 2003; pp 53-8.

436 [47] Kennedy MW. Uterocalin - provider of essential lipids and amino acids to the pre437 placentation equine conceptus. In: Havermeyer Foundation Monograph series 16, 2004; pp 438 53-6. 
[48] Ellenberger C, Wilsher S, Allen WR, Hoffmann C, Kölling M, Bazer FW et al. Immunolocalisation of the uterine secretory proteins uterocalin, uteroferrin and uteroglobin in the mare's uterus and placenta throughout pregnancy. Theriogenology 2008;70:746-57. [49] Baumbach GA, Saunders PTK, Bazer FW, Roberts RM. Uteroferrin has N-asparaginelinked high-mannose-type oligosaccharides that contain mannose 6-phosphate. Proc Natl Acad Sci USA 1984;81:2985-9.

[50] Mukherjee AB, Zhang Z, ChiltonBS. Uteroglobin: A Steroid-Inducible Immunomodulatory Protein That Founded the Secretoglobin Superfamily. Endocr Rev 2007;28:707-25.

448 [51] Wilsher S, Gower S, Allen WR. Persistence of an immunoreactive MUC1 protein at the 449 feto-maternal interface throughout pregnancy in the mare. Reprod Fert Dev 2013;25:75361.

451

[52] Johnson GA, Bazer FW, Jaeger LA, Ka H, Garlow JE, Pfarrer C et al. Muc-1, integrin, and 452 osteopontin expression during the implantation cascade in sheep. Biol Reprod 2001;65:8208.

454 [53] Zhang Z, Wang Q, Wang H, Duan E. Uterine fluid in pregnancy: a biological and clinical 455 outlook. Trends Mol Med 2017;23:604-14.

456 [54] Schmelzer CH, Harris RJ, Butler D, Yedinak CM, Wagner KL, Burton LE. Glycosylation 457 pattern and disulfide assignments of recombinant human differentiation-stimulating factor. Arch Biochem Biophys 1993;302:484-9.

459 [55] Jones CJP , Aplin JD, Burton GJ. First trimester histiotrophe shows altered sialylation compared with secretory phase glycoconjugates in human endometrium. Placenta 2010;31:576-80.

462 [56] Graham RA, Li TC, Cooke ID, Aplin JD. Keratan sulphate as a secretory product of human 463 endometrium: cyclic expression in normal women. Hum Reprod 1994;9:926-30.

464 [57] Kastelic JP, Adams GP, Ginther OJ. Role of progesterone in mobility, fixation, 465 orientation, and survival of the equine embryonic vesicle. Theriogenology. 1987;27:655-63. 466 [58] Heap RB, Hamon M, Allen WR. Studies on oestrogen synthesis by the preimplantation 467 equine conceptus. J Reprod Fertil Suppl 1982;32:343-52.

468 [59] Choi S-J, Anderson GB, Roser JF. Production of free estrogens and estrogen conjugates 469 by the preimplantation equine embryo. Theriogenology 1997;47:457-66. 
[60] Medved'ová L, Farkaš R. Hormonal control of protein glycosylation: Role of steroids and

471 related lipophilic ligands. Endocr Regul 2004;38:65-79.

472 [61] Swegen A, Grupen C, Gibb Z, Baker M, De Ruijter-Villani, Smith, ND et al. From peptide masses to pregnancy maintenance: a comprehensive proteomic analysis of the early equine embryo secretome, blastocoel fluid and capsule. Proteomics 2017;17:1600433.

Figure Legends:

Figure 1: Staining by VVA over the course of the oestrous cycle and early pregnancy.

479 A. Estrus: Ciliated and non-ciliated cells show weak staining with a few darker inclusions; the microvillous surface and cilia are more heavily stained. B. Day 5 post-ovulation: Cells are more regular and columnar than those seen at estrus, with apical granules of moderate density in the non-ciliated cells. Those with cilia are now more numerous and generally paler with a few dark supranuclear inclusions. C. Day 5 post-ovulation: Low power view showing the gland staining diminishing basally and some heterogeneity of stain in the midregions of the gland. D. Day 8 post-ovulation: Cells appear much as at Day 5. Inset: Negative control with substitution of buffer for lectin. E. Day 12 post-ovulation: Ciliated cells continue to be paler than their secretory counterparts; their cilia are very prominent. F. Day 15 post-ovulation: The non-ciliated cells show variable staining and ciliated cells are slightly paler, the epithelium seems slightly shorter than previously. Cilia are again prominent. G. Day 12 of pregnancy: The ciliated cells are now somewhat goblet shaped and packed with granules while the non-ciliated cells are very pale with few inclusions. The cilia appear somewhat ragged. H. Day 15 of pregnancy: The ciliated cells are more rounded but otherwise there is little change. Scale bars A-B, D-H: $25 \mu \mathrm{m}, \mathrm{C}: 100 \mu \mathrm{m}$. Ov: ovulation, P: pregnancy.

Figure 2: Characteristics of the secretory granules with various lectins:

A - C: LTA staining at days 5 and 15 post-ovulation and day 15 of pregnancy. Note how the darkly staining secretory granules present in the non-ciliated cells in post-ovulation stages are absent in pregnancy. D-F: SBA staining over a similar period: Initially showing intense binding of this lectin, the non-ciliated cells show less staining at day 15 post-ovulation. At 
weakly stained. G-I: Day 12 of pregnancy: PSA, WFA and MAA bind the ciliated cells to

503 different degrees. With MAA there are only a few granules that stain weakly in the apical

504 regions of the ciliated cells with little binding to the apical plasma membrane. The microvilli 505 and cilia bind WFA intensely. J-L: Day 15 of pregnancy: BSA-1B ${ }_{4}$, shows weak binding to the

506 ciliated goblet cells while non-ciliated cells have a few darkly staining granules. With PAA

507 the goblet cells contain a few supranuclear granules that bind strongly and weak to

508 moderate apical staining which is not greatly changed after neuraminidase pretreatment.

509 The non-ciliated cells also have some dark granules. The cilia are not well-formed at this

510 stage. Scale bars: $25 \mu \mathrm{m}$. Ov: Ovulation, P: Pregnancy.

511

512 Figure 3: Lectin staining of the endometrial glands.

513 A: With MAA (upper half), the glands show stronger binding in the mid to basal parts of the

514 glands. After neuraminidase treatment pretreatment, staining was reduced (lower half). (5

515 days post-ovulation). B: AHA shows somewhat coarse, granular staining (5 days post-

516 ovulation). C: The hollow nature of the secretory granules can be seen clearly with CON A

517 (estrus, basal gland). D: WFA binds in a very heterogeneous manner, especially in the mid

518 to basal glands (estrus). E: SNA-1 shows darker supranuclear binding in this mid-gland region

519 which may be Golgi-body staining (Day 5 post-ovulation). F: AHA binding at estrus; only the

520 upper parts of the glands are stained. G: After neuraminidase pretreatment of a similar

521 section, the gland binds AHA down its whole length. H: With ECA, secretions do not bind

522 very strongly in the basal glands (Day 5 post-ovulation). I: After neuraminidase pretreatment

523 of a similar section, the secretions stain up more strongly. Scale bars A, F and G: $100 \mu \mathrm{m}, \mathrm{B}-\mathrm{E}$,

$524 \mathrm{H}-\mathrm{I}: 25 \mu \mathrm{m}$. Ov: Ovulation, P: Pregnancy, N: neuraminidase pretreatment. 
Revised 2.

The influences of cycle stage and pregnancy upon cell glycosylation in the endometrium of the mare

$$
\begin{gathered}
\text { Carolyn J.P. Jones }{ }^{\mathrm{a}^{*}} \\
\text { John D. Aplin } \\
\text { W. R. (Twink) Allen }
\end{gathered}
$$

Sandra Wilsher ${ }^{\mathrm{b}}$

${ }^{a}$ Maternal and Fetal Health Research Centre, Division of Developmental Biology \& Medicine, School of Medical Sciences, Faculty of Biology, Medicine and Health, University of Manchester, Central Manchester University Hospital NHS Foundation Trust, Manchester Academic Health Sciences Centre, St Mary's Hospital, Oxford Road, Manchester M13 9WL ${ }^{b}$ Sharjah Equine Hospital, Bridge No 6, Al Daid Road, Al Atain Area, Sharjah, United Arab Emirates.

*Corresponding author: Carolyn Jones, PhD, DMedSc, Maternal and Fetal Health Research Centre, $5^{\text {th }}$ Floor (Research), St Mary's Hospital, Hathersage Road, Manchester M13 OJH, UK.

Email addresses: carolyn.jones@manchester.ac.uk (C.J.P. Jones), twinkallen100@gmail.com (W.R. Allen), john.aplin@manchester.ac.uk (J.D. Aplin), sandrawilsher@hotmail.co.uk (S. Wilsher) 


\section{Abstract}

2 From Day 6.5-7 post-conception until its loss around Day 22, the equine embryo is enclosed

3 in a mucinous capsule that prevents direct intercellular interaction between the

4 trophectoderm and uterine epithelium. The embryo is, however, bathed in glycoprotein-rich

5 secretions. In this study, lectin histochemistry was used to characterise the distribution and

6 glycan composition of uterine glycoproteins destined for secretion, and to ascertain the

7 local effect of an embryo on glycosylation in the endometrium. Endometrial biopsies were

8 taken from mares in estrus, on Days 5, 8, 12 and 15 of diestrus, and on Days 12 and 15 of

9 pregnancy and processed for lectin histochemistry. During estrus, lumenal epithelial cells were as truncated pyramids and mainly non-ciliated with glycosylated granules in the cytoplasm. Occasional ciliated cells contained few granules. Five days post-ovulation, nonciliated cells of the lumenal epithelium were taller, and had accumulated many highly glycosylated apical granules. By Days 12 and 15 post-ovulation these cells were more cuboidal and some showed fewer secretory granules. In marked contrast, by Days 12 and 15 of pregnancy, the ciliated cells were distended, with numerous granules but non-ciliated cells had only a few in the apical cytoplasm. Glycosylation changed dramatically in pregnancy in the luminal and superficial gland epithelium, with fewer fucosylated termini, more $\mathrm{N}$-acetyl galactosamine residues, together with an overall reduction in sialic acid and several other sugar structures. Glycosylation in ciliated cells on Days 12 and 15 of pregnancy showed a striking similarity to that of the blastocyst capsule. The data strongly suggests that glycoprotein production by luminal epithelial cells is influenced by the presence of a conceptus. We speculate that, as well as providing nourishment for the developing embryo, epithelial secretory glycoproteins may contribute components to the capsule, which develops only partially in embryos cultured in vitro. 


\section{Introduction}

The mammalian uterus, where cyclic changes regulate interaction with spermatozoa, the embryo and the placenta, is particularly rich in glycan expression $[1,2]$. Endometrial glands, in particular, produce secretions rich in glycoproteins and mucins that play a role in the provision of a suitable environment for the preimplantation embryo [3]. Striking variations in the uterine glycan repertoire are seen, both through the various stages of reproductive cycles and between different species [4-6]. A spatially-resolved glycosylation profile of a target tissue of interest can be derived by exposing serial sections to a panel of reportertagged carbohydrate-binding proteins known as lectins [7].

The horse conceptus is unique in that it does not make stable contact with the uterine epithelium until 40 to 42 days after ovulation [8]. The embryo enters the uterus on Day 6 after ovulation and from then until Day 16-17 it moves constantly around the uterine lumen, driven by peristaltic contractions of the myometrium stimulated by pulsatile releases of PGF2 $\alpha$ (muscle contractant) and $\mathrm{PGE}_{2}$ (relaxant) from the trophoblast [9]. During this period the conceptus remains spherical and is surrounded by the equine-unique blastocyst capsule, which is secreted initially by the early trophoblast shortly after the embryo enters the uterus $[10,11]$. This mucin-like glycoprotein capsule persists until around Day 22 when it begins to disintegrate. The capsule fails to develop correctly in embryos cultured in vitro [12], suggesting that uterine secretions may support its production and/or maintenance. Conversely, we do not know if the mobility of the equine embryo has any effect upon the secretions produced by the endometrium, although movement of the vesicle within and between the uterine horns has been proposed to have a role in physiological or metabolic exchanges between the vesicle, uterine luminal fluids or the endometrium [13].

We hypothesised that lectin histochemistry would enable us to test the hypothesis that endometrial epithelial differentiation and secretory activity are affected by the presence of a conceptus, and provide evidence that uterine secretions might contribute to capsule formation. 


\section{Materials and Methods}

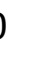

The equine endometrium was studied from estrus to Day 15 of diestrus and days 12 to 15 of pregnancy to allow comparison between non-pregnant states and pregnancy. The endometrium comprises the luminal epithelium and the lamina propria that extends from its basal lamina to the myometrium. The lamina propria is packed with endometrial glands each opening into the uterine lumen, and surrounded by stromal cells in the upper part of the lamina - the stratum compactum - and by a loose arrangement of interconnecting cells in the lower stratum spongiosum. The morphology and degree of coiling of the glands alter with the stage of the oestrous cycle and these changes in gland histology and their quantity of intraluminal secretions are well documented [14, 15].

Endometrial biopsies were obtained from cycling and early pregnant nulliparous Arabian mares 3 to 8 years old maintained at Sharjah Equine Hospital (Sharjah, U.A.E), with approval from the Hospital Ethical Committee. The mares were all of known fertility with no uterine pathology. Ovulation (Day 0) and pregnancy were confirmed by transrectal ultrasonography. Biopsies were taken from a total of 16 mares with some biopsied on two occasions at different stages of consecutive estrous cycles. All mares had shown at least one normal cycle prior to the study and those sampled during estrus went on to ovulate normally, confirmed by transrectal ultrasonography and a rise in peripheral progesterone concentrations. As estrus is such a variable length in the mare, biopsies taken during estrus $(n=3)$, were collected when mares exhibited an oedema pattern of $\geq 3$ (scale 1 to 4 , with 4 being the greatest) and exhibited a follicle on their ovaries $\geq 30 \mathrm{~mm}$. Further biopsies were taken on Days 5, 8, 12 and 15 of diestrus ( $n=3$ at each time point) and Days 12 and 15 of pregnancy ( $n=3$ at each time point). In non-pregnant mares biopsies were taken from the base of the left or right horn. In pregnant mares transrectal ultrasound examination using a Sonosite $\mathrm{M}-$ Turbo- $\mathrm{C}$ with a $7.5 \mathrm{MHz}$ linear probe prior to the biopsy determined the site of the embryo in the uterus and Yeoman's biopsy forceps were directed to the base of that uterine horn. The biopsies were fixed in $10 \%$ neutral buffered formalin. Thin slices (approximately $1 \mathrm{~mm}$ ) were post-fixed in $2.5 \%$ glutaraldehyde in $0.1 \mathrm{M}$ sodium cacodylate buffer pH 7.3 for 2 hours before being embedded in epoxy resin (Taab Laboratory Equipment, Aldermaston, UK) for lectin histochemistry. This was performed as described previously [16] using a panel of 24 lectins (see Table 1 for lectins used and their 
specificities). Some sections were pre-treated with Type VI neuraminidase from Clostridium perfringens (Sigma, 0.1 units $/ \mathrm{ml}$ in $0.2 \mathrm{M}$ acetate buffer $\mathrm{pH}$ 5.5. with $1 \%$ calcium chloride) for $2 \mathrm{~h}$ at $37^{\circ} \mathrm{C}[17]$ to cleave off terminal sialic acid residues before staining with AHA, ECA, SBA, SNA-1, MAA, PAA and WGA. Controls were performed as described previously [16]. Lectin binding was assessed using a semi-quantitative ranking system of analysis, where staining density was allocated a grade from 0 (unstained) to 4 (intensely stained) and granule distribution from -/+ (very sparse) to +++ (abundant) [16]. Images were captured on an Olympus microscope with Image-ProPlus software (Media Cybernetics, Rockville, MD, USA) using $x 10$ and $x 40$ objectives.

\section{Results}

3.1 Lumenal epithelium (Average values are summarised in Tables 2 and 3). Typical changes in glycosylation are well illustrated by the lectin VVA (Figure 1).

\subsubsection{Estrus}

During estrus, the cells of the lumenal epithelium were irregular and resembled truncated pyramids or frustra in shape, and measuring $10-20 \mu \mathrm{m}$ in height (Fig. 1A), with the majority having a microvillous surface. Occasional ciliated cells were visible, often near gland openings on the lumenal surface. Both the microvillous and ciliated apical surfaces were very heavily glycosylated, binding all lectins apart from $B S A-1 B_{4}$, although weakly with MAA. A variable number of apical granules could be seen, some individual but others in clumps, the latter mainly in the non-ciliated cells. These inclusions were stained by most lectins (Figs 1A, 3F), but only weakly by I-PHA, LTA and MAA. A subpopulation bound CONA,

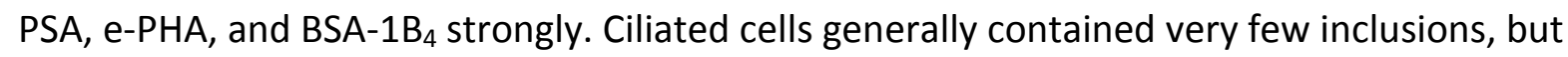
those that were present tended to have similar binding characteristics to those in the nonciliated cells.

\subsubsection{Diestrus, Days 5-15}

By Day 5 post-ovulation, the epithelial cells were more regular and columnar in shape and were now 20-25 $\mu \mathrm{m}$ high, many more ciliated cells being present (Fig. 1B); the distinction between cells with or without cilia was now more marked. The supranuclear 
areas of non-ciliated cells were packed full of secretory granules which were heavily

124 glycosylated, as evidenced by strong binding of lectins including LTA and SBA (Figs 2A, D);

125 PSA, DBA, VVA (Fig. 1B), BSA-1B 4 , WFA, and STA showed more moderate binding, and I-PHA

126 and MAA bound only weakly (Fig. 3A). The microvillous surface also bound the lectins

127 strongly, apart from I-PHA and MAA. The majority of ciliated cells had only a few, sparse

128 supranuclear inclusions which stained with all the lectins except for $\mathrm{BSA}-1 \mathrm{~B}_{4}$, as did the

129 apical surface. Little change was evident at Day 8 post-ovulation (Fig. 1D), but by Day 12

and especially Day 15 (Figs 1E, F, 2B), in the absence of an embryo, non-ciliated cells showed greater heterogeneity in lectin binding and incidence of secretory granules, suggesting that there had been some release of intracellular glycan; by day 15 they were shorter, about 10 $15 \mu \mathrm{m}$ in height. Cilia were very prominent by this stage, with some intracellular supranuclear secretory material (Figs 1E, F, 2E) present in the ciliated cells.

\subsubsection{Pregnancy, Days 12 and 15}

The presence of an embryo in the uterus induced a dramatic change in the morphology of the lumenal epithelium and its glycosylation. At Day 12 of pregnancy, the ciliated cells, though similar in height to their non-pregnant counterparts, had become goblet-shaped and swollen with apically concentrated secretory granules, but with fewer and more ragged cilia (Fig. 1G); by Day 15 they appeared rounder and their cilia looked even more degenerate (Fig. $1 \mathrm{H}$ ). As in the non-pregnant state, the abundant granules bound most of the lectins (see Table 2 and Figs $1 \mathrm{H}, 2 \mathrm{~F}, \mathrm{G}, \mathrm{H}, \mathrm{K}$,) but they were virtually unstained with lectins I-PHA, LTA, UEA-1 and MAA (Figs 2C, I). Occasional dark inclusions were seen in the case of AHA, SNA-1 and PAA (Fig. 2K). In many cases, the staining was concentrated in the upper areas of the cell as can be seen with SBA and PAA (Figs $2 \mathrm{~F}, \mathrm{~K}$ ). The occasional inclusions that bound MAA appeared to be located in the area of the Golgi apparatus, just above the nucleus.

The non-ciliated cells which, during the cycle, were full of secretions, now contained only sparse inclusions in an otherwise clear cytoplasm. The apical surface still bound most lectins apart from MAA and the occasional inclusions that were present had now lost all their binding to LTA (Fig. 2C) , UEA-1 and MAA, but otherwise, the same lectins stained as seen on Day 15 post-ovulation in non-pregnant mares. 
Pretreatment with neuraminidase had very little effect on the staining of the lumenal epithelial cells with respect to AHA, ECA, SBA, PAA (Fig. 2L) and WGA but, as expected, there was diminution of binding of the sialic acid-specific lectins SNA-1 and MAA (Fig. 3A).

\subsection{Glandular epithelium}

The results of the lectin staining in the glands are summarised in Table 3. Cell shading has been used to show changes in staining intensity in the upper, mid and basal portions of the endometrial glands at four different time points. The stated values are only approximate and they aim to illustrate the trend since great variation was evident between different gland profiles.

For many of the lectins significant differences in glycosylation existed between the upper and basal portions of glands, with staining intensity diminishing from the surface to the basal regions (see Table 3), apart from MAA (Fig. 3A) which was strongest basally. Other lectins bound more or less uniformly down the gland (CON A, PSA, e-PHA, UEA-1, ALA, DSA, STA and SNA-1) while pretreatment with neuraminidase increased staining with AHA and ECA and to a lesser extent SBA, making staining also more uniform (Fig. 3 F, G). There was virtually no binding with I-PHA and LTA showed only weak binding. Unlike the lumenal epithelium, staining of the glands did not alter greatly with the onset of pregnancy (see Table 3), with the exception that the upper part of the gland generally took on the characteristics of the lumenal epithelium, as can be seen in Fig 1G.

The uppermost parts of the glands were composed of cells very like those constituting the lumenal epithelium and they showed the same staining properties. Tufts of highly glycosylated cilia were visible and other apical surfaces of the cells bore microvilli which bound most lectins apart from I-PHA. Coarse granular supranuclear upper gland staining was seen with AHA (Fig. 3B) and MPA during estrus and up until Day 8 postovulation.

The mid-regions of the glands were composed of narrow, columnar cells with microvilli and basally situated nuclei; masses of glycan-rich granules were evident between the nuclei and apical surface. With some lectins, these granules appeared to be hollow (Fig. 3C). Generally, the staining was fairly uniform in nature despite the glands containing both secretory and ciliated cell types. However, with WFA there was very heterogeneous binding 
to the cells of the mid-portion and, later, also the basal portion of the glands, with some darkly stained cells adjacent to completely unstained ones (Fig 3D). This was also seen with DBA and, to a lesser extent, with VVA (Fig. 1C). The fact that lateral and basal areas of the cells were stained made this even more striking.

Sometimes there was darker staining just above the nucleus which may have reflected the position of the Golgi apparatus; this was particularly evident with ALA, AHA, ECA, SBA, SNA-1 (Fig. 3E) and WGA and MAA and, in general but apart from MAA, was enhanced after neuraminidase pretreatment. In the basal regions of the glands there was weak or no binding with LTA, DBA, VVA, BSA-1B, $\mathrm{HPA}, \mathrm{AHA}$ and SBA, with some variability between gland profiles. DBA binding varied, being low during estrus and variable after ovulation.

Secretory material was sometimes detected in gland lumenae, especially towards the basal portions. Occasionally, widely dilated lumenae were seen, which contained heterogeneous secretory material. The secretions bound most of the lectins tested except for I-PHA, BSA-1B ${ }_{4}$ and $\mathrm{AHA}$ (without neuraminidase), consistent with the progressive release of glycoprotein from intracellular stores. In the cases of three lectins (SBA, ECA and AHA) that recognise structures in which subterminal galactose in either $\mathrm{O}$ - or $\mathrm{N}$-linked glycans can be capped by sialic acid, thus inhibiting binding of the lectin, neuraminidase pretreatment increased the staining of secretions (Fig $3 \mathrm{H}, \mathrm{I}$ ), most notably in the mid- tobasal parts of the glands. Staining with MAA, which binds sialic acid, was reduced by neuraminidase pretreatment (Fig, 3A), providing a control for the assay.

\section{Discussion}

There have been few studies to date on uterine glycosylation in the mare. Some early work used lectins labelled with FITC to show endometrial fucose and N-acetyl glucosamine, both of which increased after implantation [18], while a limited panel of lectins was used to assess changes that occurred in chronic endometrial degeneration [19]. Jones et al. [20] examined pre-and post-implantation stages of equine pregnancy with a panel of 15 lectins and demonstrated changes occurring between Days 37 and 50 associated with commencing attachment and the start of interdigitation of the trophoblast with the endometrium. Here, we have observed changes during the oestrous cycle and early pregnancy that we postulate may be relevant to the early embryo-endometrial dialogue. 
A progressive build-up of richly and diversely glycosylated granules in non-ciliated lumenal epithelial cells is seen between Days 0 and 5 . Important features include an intense concentration of L-fucosyl residues (LTA), moderate levels of $\mathrm{N}$-acetyl galactosaminecontaining structures (DBA, VVA, WFA) and weak $\alpha 2,3$-linked sialylation (MAA). It is probable that the intracellular granules are destined for secretion as the uterus prepares itself for the possible arrival of an embryo on Day 6 post ovulation [21]. In the absence of an embryo, they gradually diminish over the next few days.

The presence of an embryo dramatically changes the lumenal epithelium with respect to both the morphology and biochemistry of the cells compared to the equivalent period during diestrus. The non-ciliated cells now contain virtually no inclusions, while ciliated cells are distended into goblet shapes with granules that contain many classes of glycan, often clustering in the apical parts of the cell where the Golgi apparatus is located [22]. Especially abundant are DBA-binding blood group A residues (GalNAca1,3(LFuc $\alpha 1,2)$ Galß1,3/4GIcNAc ß1) and shorter N-acetylgalactosamine sequences (VVA), also N-acetyl glucosamine oligomers (STA, LEA and WGA); almost all of these are absent or sparse in ciliated cells in the non-pregnant state (see Table 2). Most striking, however, is the loss in pregnancy of specific non-reducing terminal residues including $\alpha 1,2-$ linked fucose (LTA, UEA-1) from both lumenal cell types. This suggests either an embryonic fucosidase activity or a juxtacrine action to reduce epithelial fucosylation. We [2] and others [23-25] have previously pointed to fucosylated oligosaccharides as influencing embryo-epithelial interactions at implantation in mouse [23], human [24-25] and a wide range of animal species [2] with mainly epitheliochorial and haemochorial placentation. Another terminal sugar, a2,3-linked sialic acid, also declines, as revealed by diminished binding of MAA.

A striking finding of this study is the shift during early pregnancy of glycoprotein production to ciliated goblet cells. Glycosylation has been reported previously in both ciliated and non-ciliated cells of the oviducal isthmus [26] and ampulla of the horse [27] during the oestrous cycle and pregnancy. Ciliated cells with secretory characteristics have been observed in single cell RNAseq profiles of human endometrial epithelial cells [28]. As shown in the rabbit oviduct, secretory granules can be exocytosed between the basal bodies or kinetosomes of cilia [29].

An acellular capsule surrounds the blastocyst from Day 6.5-7 post-ovulation until its loss around Day 22 [10]. Between Days 6 and 16 after ovulation, the conceptus moves 
constantly throughout the uterine lumen, accruing mass up to Day $18[10,30]$ and expanding from a diameter of $150-220 \mu \mathrm{m}$ on Day 6 to around $2.5-2.8 \mathrm{~cm}$ on Day 21 [31]. It also doubles in weight during this time, suggested to be due to its accumulation of proteins and other components from uterine secretions [32]. The capsule is composed of mucins high in galactosyl and $\mathrm{N}$-acetylgalactosamine residues after Day 10 of pregnancy, with less $\mathrm{N}$-acetylglucosamine and little $\mathrm{N}$-glycan, suggesting it is heavily $\mathrm{O}$-glycosylated [33]. Although fucose was analysed in that study [33], there was no specific mention of it in the results, implying it was not a major constituent [33]. Low levels of free sialic acid were detected but cryptic sites were revealed after neuraminidase pretreatment. Thus, the glycan profile observed in goblet cells during pregnancy, with little fucose and increases in galactose and $\mathrm{N}$-acetylgalactosamine appears to be similar to that of the capsule. It is tempting, therefore, to postulate that the lumenal epithelial and gland secretions may contribute to its formation. Indeed, although it has been shown that the major part of the capsule is produced initially by the trophoblast $[10,11]$, its inability to form correctly in vitro [12] suggests that the uterine environment is essential for its development. Furthermore, demi-embryos that had lost their capsule during bisection to produce monozygotic twins developed a new capsule when transferred to the uteri of recipient mares [34].

It has also been suggested that 0 -linked glycoproteins in mucins have a fundamental role in cell-cell interactions [35], and that the capsule itself may be involved in signalling between the embryo and the endometrium. Movement of the embryo within the uterine lumen might even act as a stimulus to the lumenal epithelial cells. It has recently been shown in an ungulate (roe deer) that luminal uterine epithelium can sense the presence of the elongated embryo [36] and factors secreted from the equine conceptus may elicit a similar response. The capsule's anti-adhesive property and its net negative charge conveyed by sialic acid may well assist the equine embryo to move around within the uterus [30]; the sialidase NEU2 has been identified in the equine conceptus transcriptome [37], with mRNA levels increasing between Days 6 and 14, and this may be linked to the observed loss of sialic acid at later stages [38]. Sialic acid in $\alpha 2,3$-linkage (MAA) on the lumenal epithelium was found to be reduced in early pregnancy which could also promote attachment by reducing the surface negative charge. prior to the establishment of haemotrophic nutrition by the allantochorionic placenta. It 
has already been shown that the endometrial glycoprotein uterocalin, a lipocalin which has one $N$-glycosylation site $[41,42]$ binds to the capsule surrounding the equine embryo $[43$, 44], acting as a carrier or transport protein for such nutrients as essential lipids and amino acids [45-47]. Uterocalin has been detected immunohistochemically in the maternal epithelium during diestrus and throughout pregnancy, with higher expression in early stages [48]. Other glycosylated secretory products such as uteroferrin and uteroglobin, which both carry $\mathrm{N}$-glycosylation sites [48-50] have been identified in the lumenal epithelium and glands of the pregnant mare, as well as MUC-1 [51] which is maintained throughout pregnancy in the equid, unlike the situation in rodents, primates, ruminants and pigs [52] in which it is reduced on contact with trophoblast. Leukaemia inhibitory factor (LIF), produced by gland epithelial cells, is also present in uterine fluid [53], and is heavily glycosylated [54] with both $N$ and $O$-linked sites. With respect to histotroph production, the binding of MAA to $\alpha 2,3$-linked sialic acid was lost in the upper parts of the endometrial glands implying that residues initially sialylated lost their sialic acid prior to secretion, possibly to render the histotroph molecules more easily broken down by the conceptus [55] as well as to make the surface less negatively charged. With most glycans, however, there is an increase in staining intensity from the basal regions towards the apical, implying subtle modulation of the glycosylation machinery along the duct. It was also noted that, despite their being two cell types reported in the literature [22] - secretory and ciliated cells - the binding of the lectins was usually generally uniform apart from that of WFA, DBA and VVA as can clearly be seen in Figure 3, implying that both cell types contribute to glycan biosynthesis.

While it is well established that progesterone can both stimulate secretory behaviour in endometrial cells $[4,56]$ and influence the fixation of the embryo [57] this study has revealed that the cellular source of secretions from the endometrial lumenal epithelium changes dramatically in response to the presence of a conceptus, indicating a novel role for cell diversity in the epithelial response. Juxtacrine signalling could occur via release of oestrogen by the conceptus $[58,59]$; there is evidence that steroids can regulate both $\mathrm{N}$ and $O$-glycosylation, especially terminal sialylation and fucosylation [60]. The numerous polypeptide mediators present in the embryonic secretome may also be influential $[37,61]$.

311 The switch from microvillous to ciliated cells as the main reservoir of glycoprotein suggests a two stage secretory process, with initial release from microvillous cells controlled through 
endocrine pathways and conceptus-derived signals targeting the ciliated cell population in pregnancy.

In conclusion, lectin histochemistry has enabled distinctive changes in cell glycosylation to be observed resulting from the presence of a conceptus in the uterus. It has also provided some evidence that glycoprotein secretions in pregnancy contribute to the unique equine blastocyst capsule as well as providing nourishment for the developing embryo.

Conflicts of interest: The authors declare that they have no competing interests.

Funding: This research did not receive any specific grant from funding agencies in the public, commercial, or not-for-profit sectors.

\section{References}

[1] Carson DD. The glycobiology of implantation. Front Biosci 2002;7:1535-44.

[2] Aplin JD, Jones CJ. Fucose, placental evolution and the glycocode. Glycobiology 2012;22:470-8.

[3] Clark GF. Functional glycosylation in the human and mammalian uterus. Fertil Res Pract. 2015;1: 17.

[4] Jones CJ, Fazleabas AT, McGinlay PB, Aplin JD. Cyclic modulation of epithelial glycosylation in human and baboon (Papio anubis) endometrium demonstrated by the binding of the agglutinin from Dolichos biflorus. Biol Reprod 1998;58:20-7.

[5] Jones CJ, Aplin JD. Glycosylation at the fetomaternal interface: does the glycocode play a critical role in implantation? Glycoconjugate J 2009;26:359-66.

[6] Jones CJP, Aplin JD. Reproductive glycogenetics - a critical factor in pregnancy success and species hybridisation. Placenta 2009;30:216-9.

[7] Manning JC, Romero A, Habermann F, Garcia Caballero G, Kaltner H and Gabius H-J. Lectins: A primer for histochemists and cell biologists. Histochem Cell Biol 2017;147:199222.

[8] Allen WR, Wilsher S. A review of implantation and early pregnancy in the mare. Placenta 2009; 30: 1005-15.

[9] Allen WR, Stewart F. Equine placentation. Reprod Fertil Dev. 2001;13(7-8):623-34. 
[10] Oriol JG, Sharom FJ, Betteridge KJ. Developmentally regulated changes in the

346 glycoproteins of the equine embryonic capsule. J Reprod Fert 1993;99:653-64.

347 [11] Albihn A, Waelchli RO, Samper J, Oriol JG,B. Croy A, Betteridge KJ. Production of capsular material by equine trophoblast transplanted into immunodeficient mice.

349 Reproduction 2003;125:855-63.

350 [12] Tremoleda JL, Stout TA, Lagutina I, Lazzari G, Bevers M M, Colenbrander B et al. Effects of in vitro production on horse embryo morphology, cytoskeletal characteristics, and blastocyst capsule formation. Biol Reprod 2003;69:1895-906.

353 [13] Ginther OJ. Mobility of the early equine conceptus. Theriogenology 1983;19:603-11.

354 [14] Hammond J, Wodzicki K. Anatomical and histological changes during the oestrus cycle in the mare. Proc Roy Soc B 1941; 130:1-12.

356 [15] Kenney RM. Cyclic and pathologic changes of the mare endo-metrium as detected by biopsy, with a note on early embryonicdeath. J Am Vet Med Assoc 1978;172:241-62 [16] Jones CJP, Carter AM, Enders AC. Glycosylation at the fetomaternal interface in haemomonochorial placentae from five widely separated species of mammal: is there evidence for convergent evolution? Cells Tiss Org 2007;185:269-84. glycoconjugates. 2. Beta-galactosyl residues in $\mathrm{O}-$ and $\mathrm{N}$-linked glycans in seminiferous tubules. Histochem J 1992;24:327-36.

[18] Whyte A, Allen WR. Equine endometrium at pre-implantation stages of pregnancy has specific glycosylated regions. Placenta 1985, 6:537-42. [19] Walter I, Klein M, Handler J, Aurich JE, Reifinger M, Aurich C. Lectin binding patterns of uterine glands in mares with chronic endometrial degeneration. Am J Vet Res 2001;62:8405.

369 [20] Jones CJP, Wooding FBP, Dantzer V, Leiser R, Stoddart RW. A lectin binding analysis of 370 glycosylation patterns during development of the equine placenta. Placenta 1999;20:45-57. 371 [21] Battut I, Colchen S, Fieni F, Tainturier D and Bruyas JF Success rates when attempting to nonsurgically collect equine embryos at 144, 156 or 168 hours after ovulation. Equine Vet J

373 (Suppl)1998;25:60-2.

374 [22] Tunón A-M,Rodriguez-Martinez H, Haglund A, Albihn A, Magnusson U, Einarsson S. 375 Ultrastructure of the secretory endometrium during oestrus in young maiden and foaled mares. Equine Vet J 1995;27:382-8. 
377 [23] Jasper MJ, Care AS, Sullivan B, Ingman WV, Aplin JD, Robertson SA. Macrophage-

378 derived LIF and IL1B regulate alpha(1,2)fucosyltransferase 2 (Fut2) expression in mouse

379 uterine epithelial cells during early pregnancy. Biol Reprod 2011;84:179-88.

380 [24] Yu M, Wang J, Liu S, Wang X, Yan Q. Novel function of pregnancy-associated plasma

381 protein $\mathrm{A}$ : promotes endometrium receptivity by up-regulating $\mathrm{N}$-fucosylation. Sci

382 Rep 2017;7:5315. doi: 10.1038/s41598-017-04735-0.

383 [25] Zheng Q, Zhang D, Yang YU, Cui X, Sun J, Liang C et al. MicroRNA-200c impairs uterine 384 receptivity formation by targeting FUT4 and $\alpha 1,3-$ fucosylation. Cell Death Differ 385 2017;24:2161-72. doi: 10.1038/cdd.2017.136.

386 [26] Desantis S, Acone F, Corriero A, Deflorio M, Zubani D, Ventriglia G, Palmieri G, De Metrio G. Distribution of sialoglycoconjugates in the oviductal isthmus of the horse during anoestrus, oestrus and pregnancy: a lectin histochemistry study. Eur J Histochem 2004;48:403-12.

390 [27] Desantis S, Ventriglia G, Zubani D, Corriero A, Deflorio M, Acone F, Palmieri G, De Metrio G. Differential lectin binding patterns in the oviductal ampulla of the horse during oestrus. Eur J Histochem 2005;49:139-49.

393 [28] Wu B, Li Y, Liu Y, Jin K, Zhao K, An C et al. Cell atlas of human uterus. Biol Rxiv 2018 394 (doi.org/10.1101/267849).

395 [29] Mechant H. Secretory granules in ciliated cells of the rabbit oviduct. Expl Cell Res $396 \quad 1969 ; 56: 171-2$.

397 [30] Oriol JG. The equine embryonic capsule: practical implications of recent research. 398 Equine Vet J 1994;26:184-6.

399 [31] Betteridge KJ, Eaglesome MD, Mitchell D, Flood PF, Beriault R. Development of horse 400 embryos up to twenty-two days after ovulation: observations on fresh specimens. J Anat $401 \quad 1982 ; 135: 191-209$.

402 [32] Amoroso EC. Placentation. In: Parkes AS, editor. Marshall's Physiology of Reproduction, 403 London: Longmans, Green and Co Ltd; 1952, p. 127-311.

404 [33] Oriol JG, Betteridge KJ, Clarke AJ, Sharom FJ. Mucin-like glycoproteins in the equine 405 embryonic capsule. Mol Reprod Dev 1993;34:255-65.

406 [34] McKinnon AO, Carnevale EM, Squires EL, Carney NJ, Seidel GE. 1989. Bisection of 407 equine embryos. Equine Vet J 1989;8(Suppl.):129-33.

408 [35] Jentoft N. Why are proteins O-glycosylated? Trends Biochem Sci 1990;15:291-4. 

MP et al. Endometrial luminal epithelial cells sense embryo elongation in the roe deer independent of interferon-tau. Biol Rep 2019;101:882-92.

412 [37] Klein C, Troedsson MHT. Transcriptional profiling of equine conceptuses reveals new 413 aspects of embryo-maternal communication in the horse. Biol Reprod 2011;84:872-85.

414 [38] Arar S, Chan KH, Quinn BA, Waelchli RO, Hayes MA, Betteridge KJ, Monteiro MA. 415 Desialylation of core type 1 O-glycan in the equine embryonic capsule coincides with 416 immobilization of the conceptus in the uterus. Carbohydr Res 2007;342:1110-5.

417 [39] Enders AC, Carter AM. Comparative placentation: some interesting modifications for 418 histotrophic nutrition - a review. Placenta 2006; 27 ( Suppl):11-6.

419 [40] Jones CJ, Choudhury RH, Aplin JD. Tracking nutrient transfer at the human maternofetal 420 interface from 4 weeks to term. Placenta 2015;36:372-80.

421 [41] Crossett B, Allen WR, Stewart F. A 19 kDa protein secreted by the endometrium of the 422 mare is a novel member of the lipocalin family. Biochem J 1996;320:137-43.

423 [42] Smits K, Govaere J, Peelman L, Goossens K, de Graaf DC, Vercauteren D et al. Influence 424 of the uterine environment on the development of in vitro-produced equine embryos.

425 Reproduction 2012;143:173-81.

426 [43] Stewart F, Charleston B, Crossett B, Barker PJ, Allen WR. A novel uterine protein that 427 associates with the embryonic capsule in equids. J Reprod Fertil 1995;105:65-70.

428 [44] Stewart F, Kennedy MW, Suire S. A novel uterine lipocalin supporting pregnancy in 429 equids. Cell Mol Life Sci 2000;57:1373-8.

430 [45] Suire S, Stewart F, Beauchamp J, Kennedy MW. Uterocalin, a lipocalin provisioning the 431 preattachment equine conceptus: fatty acid and retinol binding properties, and structural 432 characterization. Biochem J 2001;356:369-76.

433 [46] Kennedy MW. Uterocalin - a provisioning protein for the equine conceptus? In 434 Proceedings of a workshop on the equine placenta. Kentucky Agricultural Experimental 435 Station, University of Kentucky, 2003; pp 53-8.

436 [47] Kennedy MW. Uterocalin - provider of essential lipids and amino acids to the pre437 placentation equine conceptus. In: Havermeyer Foundation Monograph series 16, 2004; pp 438 53-6. 
[48] Ellenberger C, Wilsher S, Allen WR, Hoffmann C, Kölling M, Bazer FW et al. Immunolocalisation of the uterine secretory proteins uterocalin, uteroferrin and uteroglobin in the mare's uterus and placenta throughout pregnancy. Theriogenology 2008;70:746-57. [49] Baumbach GA, Saunders PTK, Bazer FW, Roberts RM. Uteroferrin has N-asparaginelinked high-mannose-type oligosaccharides that contain mannose 6-phosphate. Proc Natl Acad Sci USA 1984;81:2985-9.

[50] Mukherjee AB, Zhang Z, ChiltonBS. Uteroglobin: A Steroid-Inducible Immunomodulatory Protein That Founded the Secretoglobin Superfamily. Endocr Rev 2007;28:707-25.

448 [51] Wilsher S, Gower S, Allen WR. Persistence of an immunoreactive MUC1 protein at the 449 feto-maternal interface throughout pregnancy in the mare. Reprod Fert Dev 2013;25:75361.

451

[52] Johnson GA, Bazer FW, Jaeger LA, Ka H, Garlow JE, Pfarrer C et al. Muc-1, integrin, and 452 osteopontin expression during the implantation cascade in sheep. Biol Reprod 2001;65:8208.

454 [53] Zhang Z, Wang Q, Wang H, Duan E. Uterine fluid in pregnancy: a biological and clinical 455 outlook. Trends Mol Med 2017;23:604-14.

456 [54] Schmelzer CH, Harris RJ, Butler D, Yedinak CM, Wagner KL, Burton LE. Glycosylation 457 pattern and disulfide assignments of recombinant human differentiation-stimulating factor. Arch Biochem Biophys 1993;302:484-9.

459 [55] Jones CJP , Aplin JD, Burton GJ. First trimester histiotrophe shows altered sialylation compared with secretory phase glycoconjugates in human endometrium. Placenta 2010;31:576-80.

462 [56] Graham RA, Li TC, Cooke ID, Aplin JD. Keratan sulphate as a secretory product of human 463 endometrium: cyclic expression in normal women. Hum Reprod 1994;9:926-30.

464 [57] Kastelic JP, Adams GP, Ginther OJ. Role of progesterone in mobility, fixation, 465 orientation, and survival of the equine embryonic vesicle. Theriogenology. 1987;27:655-63. 466 [58] Heap RB, Hamon M, Allen WR. Studies on oestrogen synthesis by the preimplantation 467 equine conceptus. J Reprod Fertil Suppl 1982;32:343-52.

468 [59] Choi S-J, Anderson GB, Roser JF. Production of free estrogens and estrogen conjugates 469 by the preimplantation equine embryo. Theriogenology 1997;47:457-66. 
[60] Medved'ová L, Farkaš R. Hormonal control of protein glycosylation: Role of steroids and

471 related lipophilic ligands. Endocr Regul 2004;38:65-79.

472 [61] Swegen A, Grupen C, Gibb Z, Baker M, De Ruijter-Villani, Smith, ND et al. From peptide masses to pregnancy maintenance: a comprehensive proteomic analysis of the early equine embryo secretome, blastocoel fluid and capsule. Proteomics 2017;17:1600433.

Figure Legends:

Figure 1: Staining by VVA over the course of the oestrous cycle and early pregnancy.

479 A. Estrus: Ciliated and non-ciliated cells show weak staining with a few darker inclusions; the microvillous surface and cilia are more heavily stained. B. Day 5 post-ovulation: Cells are more regular and columnar than those seen at estrus, with apical granules of moderate density in the non-ciliated cells. Those with cilia are now more numerous and generally paler with a few dark supranuclear inclusions. C. Day 5 post-ovulation: Low power view showing the gland staining diminishing basally and some heterogeneity of stain in the midregions of the gland. D. Day 8 post-ovulation: Cells appear much as at Day 5. Inset: Negative control with substitution of buffer for lectin. E. Day 12 post-ovulation: Ciliated cells continue to be paler than their secretory counterparts; their cilia are very prominent. F. Day 15 post-ovulation: The non-ciliated cells show variable staining and ciliated cells are slightly paler, the epithelium seems slightly shorter than previously. Cilia are again prominent. G. Day 12 of pregnancy: The ciliated cells are now somewhat goblet shaped and packed with granules while the non-ciliated cells are very pale with few inclusions. The cilia appear somewhat ragged. H. Day 15 of pregnancy: The ciliated cells are more rounded but otherwise there is little change. Scale bars A-B, D-H: $25 \mu \mathrm{m}, \mathrm{C}: 100 \mu \mathrm{m}$. Ov: ovulation, P: pregnancy.

Figure 2: Characteristics of the secretory granules with various lectins:

A - C: LTA staining at days 5 and 15 post-ovulation and day 15 of pregnancy. Note how the darkly staining secretory granules present in the non-ciliated cells in post-ovulation stages are absent in pregnancy. D-F: SBA staining over a similar period: Initially showing intense binding of this lectin, the non-ciliated cells show less staining at day 15 post-ovulation. At 
weakly stained. G-I: Day 12 of pregnancy: PSA, WFA and MAA bind the ciliated cells to

503 different degrees. With MAA there are only a few granules that stain weakly in the apical

504 regions of the ciliated cells with little binding to the apical plasma membrane. The microvilli 505 and cilia bind WFA intensely. J-L: Day 15 of pregnancy: BSA-1B ${ }_{4}$, shows weak binding to the

506 ciliated goblet cells while non-ciliated cells have a few darkly staining granules. With PAA

507 the goblet cells contain a few supranuclear granules that bind strongly and weak to

508 moderate apical staining which is not greatly changed after neuraminidase pretreatment.

509 The non-ciliated cells also have some dark granules. The cilia are not well-formed at this

510 stage. Scale bars: $25 \mu \mathrm{m}$. Ov: Ovulation, P: Pregnancy.

511

512 Figure 3: Lectin staining of the endometrial glands.

513 A: With MAA (upper half), the glands show stronger binding in the mid to basal parts of the

514 glands. After neuraminidase treatment pretreatment, staining was reduced (lower half). (5

515 days post-ovulation). B: AHA shows somewhat coarse, granular staining (5 days post-

516 ovulation). C: The hollow nature of the secretory granules can be seen clearly with CON A

517 (estrus, basal gland). D: WFA binds in a very heterogeneous manner, especially in the mid

518 to basal glands (estrus). E: SNA-1 shows darker supranuclear binding in this mid-gland region

519 which may be Golgi-body staining (Day 5 post-ovulation). F: AHA binding at estrus; only the

520 upper parts of the glands are stained. G: After neuraminidase pretreatment of a similar

521 section, the gland binds AHA down its whole length. H: With ECA, secretions do not bind

522 very strongly in the basal glands (Day 5 post-ovulation). I: After neuraminidase pretreatment

523 of a similar section, the secretions stain up more strongly. Scale bars A, F and G: $100 \mu \mathrm{m}, \mathrm{B}-\mathrm{E}$,

$524 \mathrm{H}-\mathrm{I}: 25 \mu \mathrm{m}$. Ov: Ovulation, P: Pregnancy, N: neuraminidase pretreatment. 
Author contribution: WRA and SW obtained the specimens and contributed to the writing, CJPJ processed, stained, analysed the tissue and contributed to the writing, JDA contributed to the writing, interpretation of the findings and advised on glycobiology. 
Table 1: Lectins used in this study, their source and major specificity.

\begin{tabular}{|c|c|c|}
\hline ACRONYM & SOURCE & MAJOR SPECIFICITY \\
\hline CON A & $\begin{array}{l}\text { Canavalia ensiformis } \\
\text { Jackbean }\end{array}$ & $\begin{array}{l}\alpha \text {-D-glucosyl and } \alpha \text {-D-mannosyl (terminal or } 1,2 \text { linked) in high } \\
\text { mannose, intermediate and small complex } \mathrm{N} \text {-linked sequences }\end{array}$ \\
\hline PSA & $\begin{array}{l}\text { Pisum sativum } \\
\text { Garden Pea }\end{array}$ & $\begin{array}{l}\alpha \text {-D-mannose in non-bisected bi/tri-antennary, complex } \mathrm{N} \text { - linked } \\
\text { sequences }\end{array}$ \\
\hline e-PHA & $\begin{array}{l}\text { Phaseolus vulgaris } \\
\text { (erythroagglutinin) } \\
\text { Kidney Bean }\end{array}$ & Bi/tri-antennary bisected complex $\mathrm{N}$-linked sequences \\
\hline I-PHA & $\begin{array}{l}\text { Phaseolus vulgaris } \\
\text { (leukoagglutinin) } \\
\text { Kidney Bean }\end{array}$ & Tri/tetra-antennary, non- bisected complex $\mathrm{N}$-linked sequences \\
\hline UEA-1 & $\begin{array}{l}\text { Ulex europaeus-1 } \\
\text { Gorse }\end{array}$ & H type 2 antigen ( $\alpha$ L-Fuc $(1,2)$ Galß1,4GlcNAcß1-) and Le ${ }^{y}$ \\
\hline LTA & $\begin{array}{l}\text { Tetragonolobus } \\
\text { purpureus } \\
\quad \text { Lotus }\end{array}$ & $\begin{array}{l}\text { L-fucosyl terminals (especially where clustered), Fuc } \alpha 1,6 \mathrm{GlcNAc} \\
\text { >Fuc } \alpha 1,2 \text {-Galß1,4(Fuc } \alpha 1,3) \text { GlcNAcß, Le }\end{array}$ \\
\hline ALA & $\begin{array}{l}\text { Aleuria aurantia } \\
\text { Mushroom }\end{array}$ & Fucose linked $\alpha 1,6-$ to GlcNAc \\
\hline DBA & $\begin{array}{l}\text { Dolichos biflorus } \\
\text { Horse Gram }\end{array}$ & GalNAc $\alpha 1,3($ LFuc $\alpha 1,2)$ Galß1,3/4GlcNAcß1- \\
\hline VVA & $\begin{array}{l}\text { Vicia villosa } \\
\text { Hairy vetch }\end{array}$ & GalNAc $\alpha 1$-Ser/Thr and GalNAc $\alpha 1,3 \mathrm{Gal} ß 1-$ \\
\hline MPA & $\begin{array}{l}\text { Maclura pomifera } \\
\text { Osage orange }\end{array}$ & Galß1,3GalNAc $\alpha 1-\quad>$ GalNAca1- \\
\hline $\mathrm{BSA}-1 \mathrm{~B}_{4}$ & $\begin{array}{l}\text { Bandeiraea simplicifolia } \\
\text { Griffonia }\end{array}$ & Gala1,3Galß1,4GlcNAcß1- \\
\hline DSA & $\begin{array}{l}\text { Datura stramonium } \\
\text { Jimson Weed }\end{array}$ & B1,4GlcNAc, N-Acetyl lactosamine >chitotriose \\
\hline STA & $\begin{array}{l}\text { Solanum tuberosum } \\
\text { Potato }\end{array}$ & B1,4GlcNAc oligomers \\
\hline LEA & $\begin{array}{l}\text { Lycopersicon esculentum } \\
\text { Tomato }\end{array}$ & B1,4GlcNAc oligomers \\
\hline HPA & $\begin{array}{r}\text { Helix pomatia } \\
\text { Roman snail } \\
\end{array}$ & Terminal GalNAc $\alpha 1-$ \\
\hline $\mathrm{AHA}$ & $\begin{array}{l}\text { Arachis hypogaea } \\
\text { Peanut }\end{array}$ & Galß1,3GalNAcß1- $>$ Galß1,4GlcNAcß1- \\
\hline ECA & $\begin{array}{l}\text { Erythrina cristagalli } \\
\text { Coral Tree }\end{array}$ & Galß1,4GlcNAcß1- \\
\hline SBA & $\begin{array}{l}\text { Glycine max } \\
\text { Soybean }\end{array}$ & Terminal GalNAc $\alpha 1-\quad>$ Gal $\alpha 1$ \\
\hline WFA & $\begin{array}{l}\text { Wisteria floribunda } \\
\text { Wisteria }\end{array}$ & GalNAc $\alpha 1,6$ Galß1- $>$ GalNAc $\alpha 1,3$ Galß1- \\
\hline SNA-1 & $\begin{array}{l}\text { Sambucus nigra } \\
\text { Elderberry Bark }\end{array}$ & NeuNAc $\alpha 2,6 \mathrm{Gal} / \mathrm{GalNAc}$ \\
\hline MAA & Maackia amurensis & NeuNAca2,3Galß1- \\
\hline PAA & $\begin{array}{l}\text { Phytolacca americana } \\
\text { Pokeweed }\end{array}$ & Similar to WGA \\
\hline WGA & $\begin{array}{l}\text { Triticum vulgaris } \\
\text { Wheatgerm }\end{array}$ & $\begin{array}{l}\text { Di-N-acetyl chitobiose, } \mathrm{N} \text {-acetyl lactosamine (especially if } \\
\text { clustered) and some sialyl residues }\end{array}$ \\
\hline
\end{tabular}


Table 2: Comparison of lectin binding at 15 days post-ovulation $(\mathrm{Ov}+15)$ and Day 15 of pregnancy (Preg Day 15) in non-ciliated and ciliated/goblet cells of the luminal epithelium with average values given the considerable inter-cell variation in stain. Staining: 0 (unstained) to 4 (intensely stained) and granule distribution from -/+ (very sparse) to +++ (abundant). ap: mainly apical staining. MV:microvilli, G: Golgi body staining

Lectins in bold show most significant changes between the non-pregnant and pregnant state. Note change of high numbers of secretory granules from non-ciliated to ciliated/goblet cells in pregnancy.

\begin{tabular}{|c|c|c|c|c|c|c|c|c|}
\hline \multirow[t]{3}{*}{ Lectin } & \multicolumn{4}{|c|}{ Non-ciliated cells } & \multicolumn{4}{|c|}{ Ciliated/goblet cells } \\
\hline & \multicolumn{2}{|c|}{ Ov + 15} & \multicolumn{2}{|c|}{ Preg Day 15} & \multicolumn{2}{|c|}{ Ov + 15} & \multicolumn{2}{|c|}{ Preg Day 15} \\
\hline & MV & Granules & MV & Granules & Cilia & Granules & Cilia & Granules \\
\hline CONA & 4 & $3+++$ & 4 & $3-/+$ & 4 & $4+$ & 4 & $3+++$ \\
\hline PSA & 3 & $2+++$ & 3 & $4-/+$ & 3 & $4+$ & 3 & $3+++$ \\
\hline ePHA & 3 & $3+++$ & 4 & $3-/+$ & 1 & $3+$ & 4 & $3+++$ \\
\hline $\mathrm{IPHA}$ & 2 & $1+++$ & 2 & 0 & 2 & 0 & 2 & $1+++$ \\
\hline LTA & 3 & $3+++$ & 2 & 1 & 2 & 2 & 2 & $1+++$ \\
\hline UEA-1 & 3 & $3+++$ & 3 & 1 & 2 & $3+$ & 2 & $1+++$ \\
\hline ALA & 3 & $3+++$ & 3 & $3+$ & 2 & $3+$ & 3 & $2-3+++$ \\
\hline DBA & 4 & $2-3+++$ & 2 & $3+$ & 4 & $3+$ & 3 & $4+++$ \\
\hline VVA & 3 & $2-3+++$ & 2 & $2-3+$ & 3 & $2-3+$ & 2 & $4+++$ \\
\hline MPA & 3 & $3+++$ & 3 & $3++$ & 2 & $2+$ & 3 & $1-2++$ \\
\hline $\mathrm{BSA}-1 \mathrm{~B}_{4}$ & 3 & $2-3+++$ & 3 & $4++$ & 1 & 1 & 1 & $1+++$ \\
\hline DSA & 4 & $4+++$ & 4 & $4+$ & 3 & $3+$ & 2 & $2-3+++$ \\
\hline STA & 4 & $3+++$ & 3 & $4+$ & 4 & $3+$ & 3 & 4+++ap \\
\hline LEA & 4 & $4+++$ & 4 & $4+$ & 3 & $3+$ & 4 & 4++ap \\
\hline HPA & 4 & $3+++$ & 4 & $4+$ & 4 & $3+$ & 4 & $4+++a p$ \\
\hline $\mathrm{AHA}$ & 4 & $3++$ & 3 & $4++$ & 2 & $3+$ & 2 & $3-4+a p$ \\
\hline ECA & 4 & $4+++$ & 4 & $4++$ & 2 & $2-3+$ & 2 & $1-2+++$ \\
\hline SBA & 4 & $4+++$ & 4 & $3+$ & 4 & $3+$ & 4 & $4+++a p$ \\
\hline WFA & 4 & $3+++$ & 4 & $3+$ & 4 & $3+$ & 4 & $4+++a p$ \\
\hline SNA-1 & 4 & $4+++$ & 3 & $3+$ & 4 & $2+$ & 3 & $2+++/ 4+$ \\
\hline MAA & 2 & $2+++$ & 1 & 0 & 3 & $2+$ & 1 & $2-3+G$ \\
\hline PAA & 4 & $4+++$ & 4 & $4-/+$ & 3 & $3+$ & 4 & $2+++/ 4+$ \\
\hline WGA & 4 & $4+++$ & 4 & $4+$ & 4 & $3+$ & 4 & 4++ap \\
\hline
\end{tabular}


Table 3: Average values of lectin binding in glandular epithelium: upper, mid and basal levels at estrus, Days 5 and 15 post-ovulation and Day 15 of pregnancy. Grades from 0 (negative, white) to 4 (intense, dark grey).

*Range between 2-4 **Range between 1-4 (Ov: ovulation, P: pregnancy)

\begin{tabular}{|c|c|c|c|c|c|c|c|c|c|c|c|c|}
\hline \multirow[t]{2}{*}{ Lectin } & \multicolumn{3}{|c|}{ Estrus } & \multicolumn{3}{|c|}{ Ov +5 } & \multicolumn{3}{|c|}{ Ov + 15} & \multicolumn{3}{|c|}{ P15 } \\
\hline & Upper & Mid & Basal & Upper & Mid & Basal & Upper & Mid & Basal & Upper & Mid & Basal \\
\hline CONA & 2 & $2 \cdot 5$ & $2 \cdot 5$ & 3 & 3 & 3 & 3 & 3 & $2 \cdot 5$ & 2 & 3 & 3 \\
\hline PSA & 2 & 3 & 3 & 3 & 3 & 3 & 2 & 2 & 2 & 2 & 2 & 2 \\
\hline e-PHA & 2 & 3 & 2.5 & 3 & 2 & 2 & 2 & 2 & 2 & 2 & 2.5 & 2.5 \\
\hline I-PHA & 0.5 & 0.5 & 0.5 & 0.5 & 0.5 & 0.5 & 0.5 & 0.5 & 0.5 & 0.5 & 0.5 & 0.5 \\
\hline LTA & 1 & 0 & 0 & 1.5 & 0.5 & 0.5 & 1 & 1 & 1 & 1 & 1.5 & 1.5 \\
\hline UEA-1 & $3 \cdot 5$ & 2.5 & $3 \cdot 5$ & 3.5 & 3 & 3 & 3 & 3 & 3 & $2 \cdot 5$ & $2 \cdot 5$ & $2 \cdot 5$ \\
\hline ALA & 2 & 2.5 & 2.5 & 2 & 2 & 2 & 3 & 3 & 3 & 2.5 & 2.5 & $2 \cdot 5$ \\
\hline DBA & 3* & $2 \cdot 5^{* *}$ & 0.5 & 3.5 & $2 \cdot 5^{* *}$ & 0.5 & 3.5 & $2 \cdot 5$ & 0.5 & $2 \cdot 5 * *$ & 2.5 & 0.5 \\
\hline VVA & $2 \cdot 5$ & $2 \cdot 5^{* *}$ & 0.5 & $3 \cdot 5$ & $2 \cdot 5 * *$ & 0.5 & $3 \cdot 5$ & $2 \cdot 5$ & 0.5 & $3 \cdot 5$ & $2 \cdot 5$ & 1.5 \\
\hline MPA & $3^{*}$ & 3* & $3^{*}$ & 3* & $3^{*}$ & $2 \cdot 5$ & $2-4$ & $3 \cdot 5$ & $2 \cdot 5$ & $2 \cdot 5$ & $2 \cdot 5$ & $2 \cdot 5$ \\
\hline $\mathrm{BSA}^{-1 \mathrm{~B}_{4}}$ & 1.5 & 0.5 & 0.5 & $2 \cdot 5$ & 0.5 & 0.5 & 1.5 & 0.5 & 0.5 & 3.5 & 0.5 & 0.5 \\
\hline DSA & 3 & 3 & 3 & $3 \cdot 5$ & 3 & $2 \cdot 5$ & 3 & 3 & $2 \cdot 5$ & 3 & 3 & $2 \cdot 5$ \\
\hline STA & 3 & $3 \cdot 5$ & $3 \cdot 5$ & $2 \cdot 5$ & $2 \cdot 5$ & $2 \cdot 5$ & 3 & 3 & 3 & $3 \cdot 5$ & 3 & $2 \cdot 5$ \\
\hline LEA & $2 \cdot 5$ & $2 \cdot 5$ & 1.5 & $2 \cdot 5$ & $2 \cdot 5$ & 1.5 & $2 \cdot 5$ & $2 \cdot 5$ & 1.5 & $3 \cdot 5$ & $2 \cdot 5$ & 2 \\
\hline HPA & 3.5 & 3.5 & 1.5 & 3.5 & 2.5 & 1.5 & $2 \cdot 5$ & 1.5 & 1.5 & $2 \cdot 5$ & 2.5 & 1.5 \\
\hline AHA & 3.5 & $2 \cdot 5^{* *}$ & 0.5 & $2 \cdot 5 * *$ & 0.5 & 0.5 & 2.5 & 0.5 & 0.5 & 3.5 & 0.5 & 0.5 \\
\hline$A H A+N$ & $3 \cdot 5$ & $3 \cdot 5$ & $3 \cdot 5$ & $3^{*}$ & $3^{*}$ & $2 \cdot 5$ & $2 \cdot 5$ & 1.5 & 1.5 & $2 \cdot 5$ & 1.5 & 2 \\
\hline ECA & 3.5 & 3.5 & 2 & 3.5 & 3.5 & 2 & 3 & 3 & 0.5 & 3.5 & 2.5 & 2 \\
\hline $\mathrm{ECA}+\mathrm{N}$ & 3.5 & 3.5 & 3.5 & 3.5 & 3.5 & $3 \cdot 5$ & 3 & 3.5 & 3.5 & 3 & 3 & 3 \\
\hline SBA & $3 \cdot 5$ & 3.5 & 0.5 & 3.5 & $2 \cdot 5$ & 0.5 & 3 & $2 \cdot 5$ & 0.5 & $3 \cdot 5$ & 3 & 0.5 \\
\hline SBA+N & 3.5 & $3 \cdot 5$ & 2.5 & $3 \cdot 5$ & 3 & $2 \cdot 5$ & 3 & 3 & 2 & $3 \cdot 5$ & 3 & 2 \\
\hline WFA & 3.5 & $2 \cdot 5^{* *}$ & 0.5 & 3.5 & $2 \cdot 5 * *$ & 0.5 & 4 & $3 \cdot 5$ & $2 \cdot 5^{* *}$ & 4 & 3.5 & $2 \cdot 5^{* *}$ \\
\hline SNA-1 & $3 \cdot 5$ & $3 \cdot 5$ & $3 \cdot 5$ & $3 \cdot 5$ & $3 \cdot 5$ & 3 & 3 & 3 & 3 & 3 & 3 & 3 \\
\hline PAA & $3 \cdot 5$ & $2 \cdot 5$ & 0.5 & $3 \cdot 5$ & 3 & 1.5 & 3 & 3 & 1.5 & $3 \cdot 5$ & 3 & 1.5 \\
\hline WGA & 3.5 & 3.5 & $2 \cdot 5$ & 3.5 & 3 & $2 \cdot 5$ & $3 \cdot 5$ & 3 & 2 & 3.5 & 2.5 & 2.5 \\
\hline MAA & 1.5 & 3.5 & 3.5 & 1.5 & 2.5 & 2.5 & 1.5 & 3 & $2 \cdot 5$ & 1.5 & 2.5 & 2.5 \\
\hline
\end{tabular}




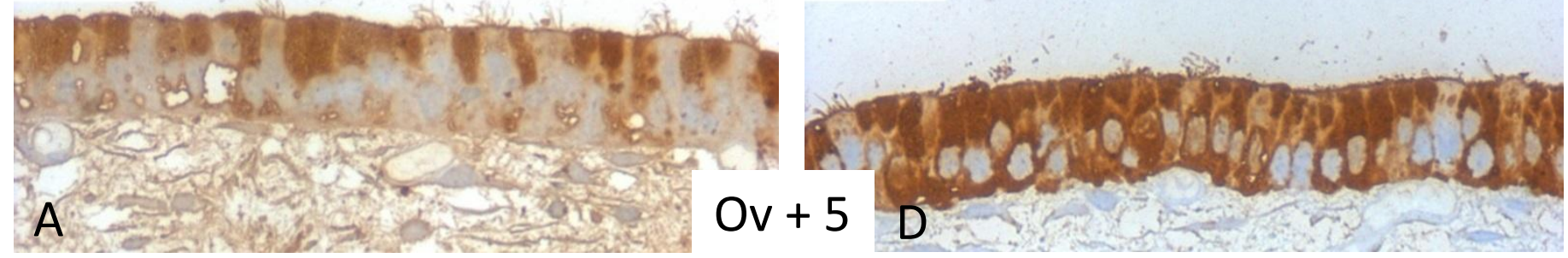

$A=O v+5 D$

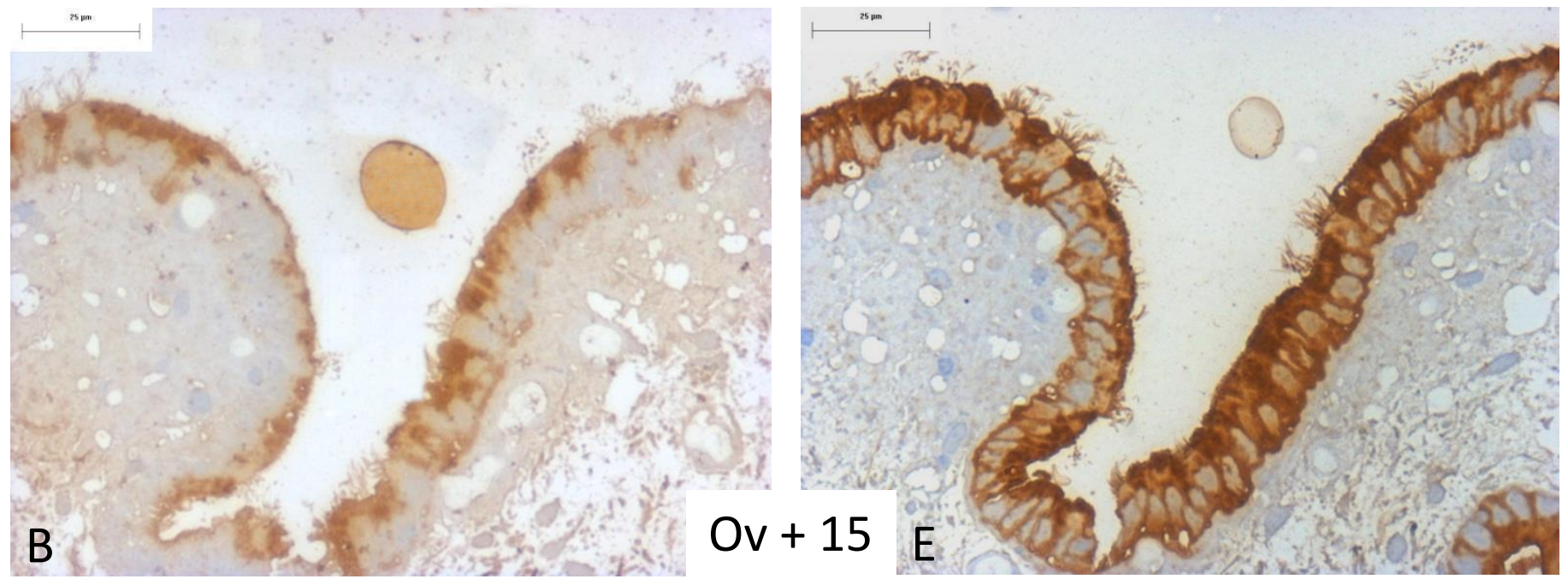

c

$$
\text { Day } 12 \quad \text { Pregnancy } \quad \text { Day } 15
$$

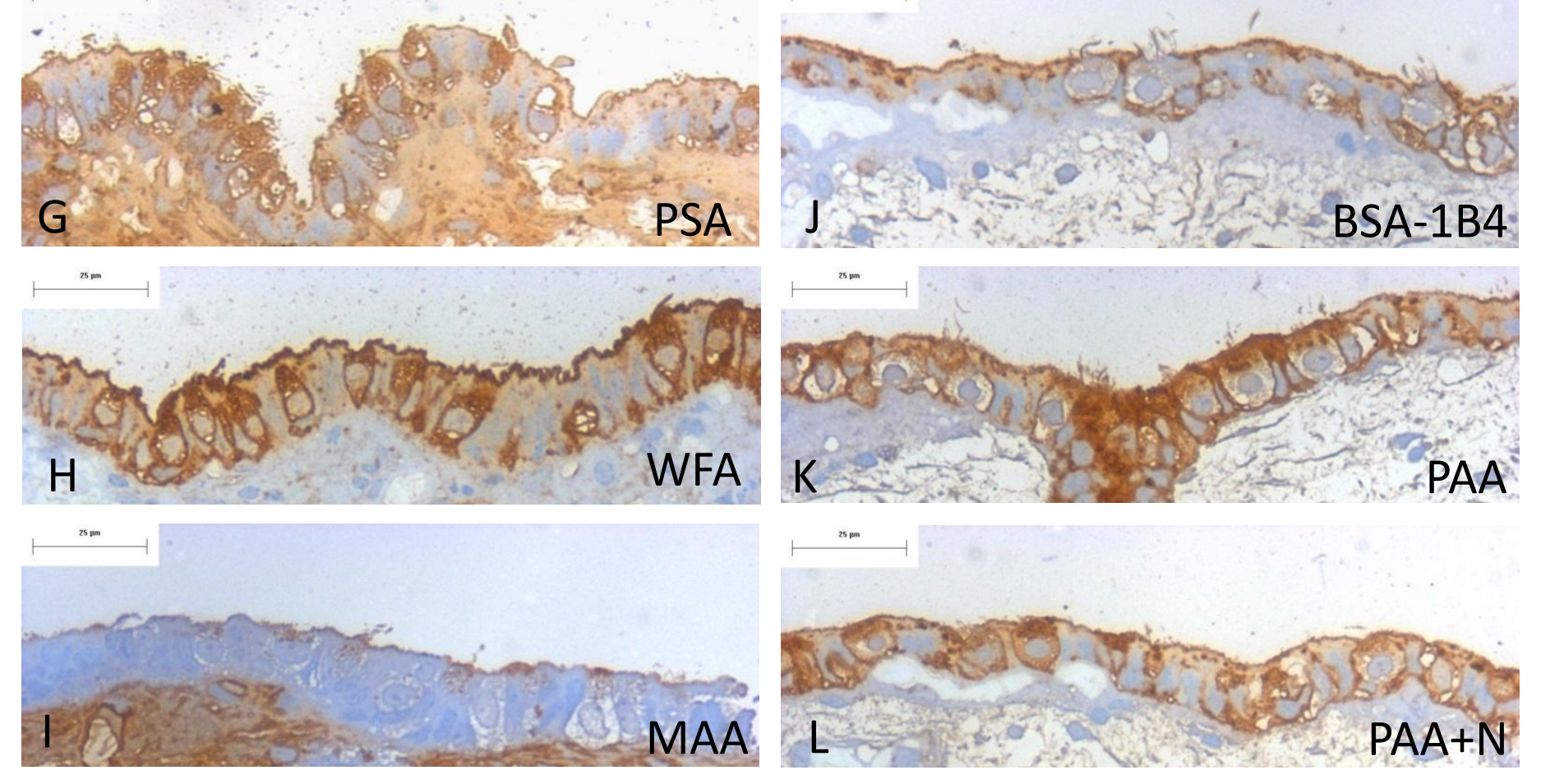


